Int. J. Dev. Biol. 53: 393-409 (2009)

doi: $10.1387 / \mathrm{ijdb} .082671 \mathrm{pw}$

\title{
Foetal germ cells: striking the balance between pluripotency and differentiation
}

\author{
PATRICK WESTERN* \\ Murdoch Children's Research Institute, ARC Centre of Excellence in Biotechnology and Development, \\ Department of Paediatrics, University of Melbourne, Royal Children's Hospital, Melbourne, VIC., Australia
}

\begin{abstract}
The germ line is unique in that highly specialised cells must be formed while retaining genomic totipotency. In mice, germ cells are derived from the pluripotent epiblast cells under the influence of inductive signals. This specification event involves reactivation or maintenance of core regulators of pluripotency, activation of germ line specific genetic programs, silencing of somatic cell programs and strict epigenetic management. These programs are thought to allow germ line specification while at the same time protecting underlying genomic totipotency. At this stage germ cells do not exhibit overt pluripotency but are able to establish pluripotent embryonic germ cells in culture. The primordial germ cells migrate to and populate the gonads at around embryonic day $\mathbf{1 0 . 5}$ and then undergo further epigenetic reprogramming and sex determination. Under the influence of the gonadal somatic cells the germ cells commit to male development and enter mitotic arrest or commit to female development and enter meiosis. This process involves down regulation of the core regulators of pluripotency, further differentiation of the germ cells, tight cell cycle regulation and loss of the germ cells ability to form pluripotent cells in culture. If this differentiation process is disrupted, germ cells can regain pluripotency and form tumours. This review focuses on the formation and early differentiation of germ cells in mammals with particular emphasis on the balance between germ cell differentiation and the maintenance of underlying genomic totipotency.
\end{abstract}

KEY WORDS: germ cell, pluripotent, cell cycle, teratoma

\section{Introduction}

The passage of genetic material from one generation to the next is fundamental to perpetuation of a species. It is exclusively the role of the germ cell lineage to deliver an individual's DNA, together with its accumulated mutations and epigenetic marks to the next generation. In many species development of the germ cell lineage is pre-determined; inheritance of maternal proteins direct germ cell specification from the outset of development. By contrast, in mammals all cells of the primitive ectoderm (the epiblast) are capable of differentiating into all cell lineages of the embryo including the germ line. It is from these pluripotent epiblast cells that the mouse germ lineage is derived (Surani et al., 2007). Germ cell specification in mouse involves inductive signals from neighbouring extraembryonic tissues, which are required for germ cell lineage recruitment from the pluripotent epiblast.

Not withstanding these differences in specification between different classes, the germ cell lineages of all animals must generate totipotency following fusion of the gametes at fertilisation In this context genomic totipotency refers to the capacity of the genome to direct the differentiation of all cell lineages required for viable development of an individual from a single cell. To achieve this, germ cells must retain genetic programmes underlying genomic totipotency, silence genetic programs promoting somatic differentiation and establish epigenetic patterns to support these characteristics. In addition, the germ cells must reset existing epigenetic patterns that are incompatible with transition to the next generation. Following these changes the germ cell lineage loses its developmental bipotentiality as it commits to either spermatogenesis in the male or to oogenesis in the female (Fig. 1). On rare occasions this balance between differentiation

\footnotetext{
Abbreviations used in this paper: BMP, bone morphogenetic protein; EG, embryonic germ; TGCT, testicular germ cell tumor; TNAP, tissue nonspecific alkaline phosphatase.
}

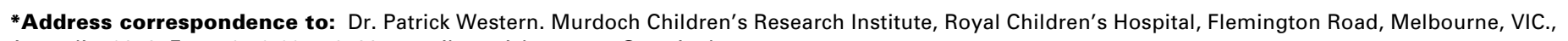
Australia, 3052. Fax: +61-3-8341-6429. e-mail: patrick.western@mcri.edu.au

Published online: 28 April 2009.

ISSN: Online 1696-3547, Print 0214-6282 
and underlying developmental totipotency is disrupted and germ cell derived cancer ensues. This review will focus on the formation and early differentiation of germ cells in mammals with particular focus on the balance between germ cell differentiation and the maintenance of underlying genomic totipotency.

\section{Origin of mouse germ cells: establishing and maintain- ing underlying totipotency}

In mouse, germ cells are derived from the pluripotent cells of the proximal epiblast (Gardner and Rossant, 1979). Early experiments showed that between E7.5-8.5 (embryonic day) the nascent germ cells could be visualised at the base of the allantois due to their high levels of tissue non-specific alkaline phosphatase (TNAP) (Snow, 1981; Ginsburg et al., 1990; McLaren, 2003) (Fig. 1). Lineage tracing experiments of single E6 - E6.5 epiblast cells in mice have shown that the germ cells originate from the region of the epiblast proximal to the extraembryonic ectoderm. At this stage these cells are not committed to germ cell development but can give rise to other cell lineages (Lawson and Hage, 1994). In addition, cells from more distant locations such as the distal tip of the epiblast can give rise to PGCs provided they are transplanted to the proximal epiblast, which is important for

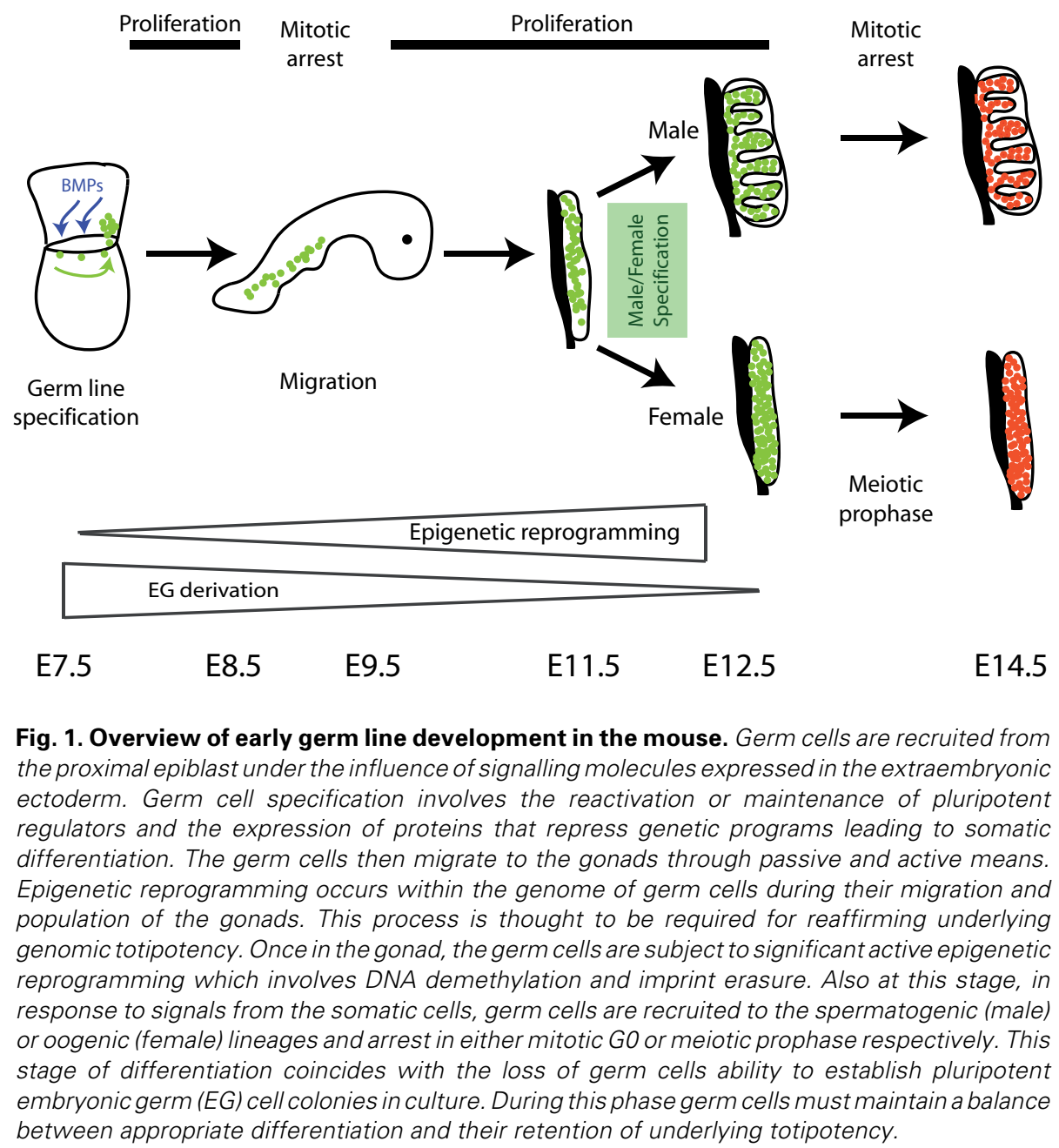

the induction of germ cells (Tam and Zhou, 1996). The specification of these cells from the proximal epiblast is dependent on extracellular signals including BMP4, BMP2 and BMP8b, which emanate from the extraembryonic ectoderm (Lawson et al., 1999; Ying et al., 2001; Ying and Zhao, 2001; Zhao and Garbers, 2002; de Sousa Lopes et al., 2004; Itman et al., 2006). During gastrulation, the putative germ cells become localised to the proximal posterior region and become located at the base of the developing allantois (Saitou et al., 2002; Ohinata et al., 2005). At the time of specification, a population of approximately 40 founding germ cells are detected (Lawson and Hage, 1994). From the base of the allantois, the PGCs migrate through the developing hindgut and finally enter into the developing gonads-(Wylie, 1999) (Fig. 1).

Recent work has substantially extended the understanding of the molecular processes underlying specification of germ cells in mouse. To this end, gene expression screens were employed to identify key genes expressed in early germ cells. In an elegant series of experiments tissue containing the nascent PGCs and neighbouring somatic cells was dissected from E7.5 embryos and single cells were used to prepare cDNA libraries (Saitou et al., 2002). Libraries that exhibited high levels of the somatic marker Hoxb1 were designated as belonging to the neighbouring "somatic" cells while those exhibiting high levels of TNAP were designated as being "germ" cell in origin. Comparisons between these libraries resulted in the identification of two novel genes, Fragilis and Stella, which were expressed in nascent germ cells (Saitou et al., 2002). At a similar time screening of gonadal germ cells also resulted in identification of these genes (Sato et al., 2002; Tanaka and Matsui, 2002). Fragilis (also known as Mil1 or Inftn3) encodes an interferon inducible transmembrane protein important for cell-cell adhesion of germ cell progenitors (Saitou et al., 2002; Tanaka et al., 2002; Lange et al., 2003; Tanaka et al., 2004; Tanaka et al., 2005). Stella (also known as Pgc7) encodes a protein containing a putative SAP domain, which may function in the regulation of chromatin (Saitou et al., 2002; Sato et al., 2002). Stella is expressed in pre-implantation embryos, in embryonic stem cells and in primordial germ cells from E7.2. Despite its striking expression in nascent germ cells, Stella does not have a detectable effect on germ cell specification (Payer et al., 2003; Bortvin et al., 2004), but is required during pre-implantation development where it may function in maintaining DNA methylation patterns (Nakamura et al., 2007). Nevertheless, the Stella promoter region has been used to make Stella-eGFPtransgenic mice that have been valuable in the analysis of germ cell specification (Payer et al., 2006; Seki et al., 2007)

The isolation of single nascent germ cells also allowed analysis of gene expression programs during the early specification of 
the mouse germ cell lineage. Establishment of genetic programmes promoting germ cell specification involves the establishment of unique epigenetic states within the nascent germ cells (Saitou et al., 2002; Ohinata et al., 2005; Seki et al., 2005; Seki et al., 2007; Surani et al., 2007) (Fig. 2). In addition, a striking feature of nascent germ cells is their ability to silence expression of genes that may otherwise lead to somatic differentiation (Saitou et al., 2002; Ohinata et al., 2005; Yabuta et al., 2006) (Fig. 2). Similar silencing of genetic programs that promote somatic differentiation is a common feature of germ cell specification in many species and is thought to be required to maintain germ cell identity and underlying pluripotency (Seydoux and Braun, 2006; Strome and Lehmann, 2007). In mouse, a critical protein in this process is BLIMP1 (also known as PRDM1), which contains an $\mathrm{N}$-terminal proline rich region and a SET (Suv39, Enhancer of Zeste, Trithorax) domain. Although the molecular function of Blimp1 is not well understood, its expression is first detected in a population of approximately 6 proximal epiblast cells that are in contact with the extraembryonic ectoderm at E6.25. This Blimp1 positive population eventually produces around 40 founding nascent germ cells at approximately E7.25. Loss of Blimp1 function results in loss of the founder population of primordial germ cells with only a few aberrant cells remaining, which fail to suppress somatic gene expression programs, cease to proliferate and cannot migrate (Ohinata et al., 2005). BLIMP1 has been shown to associate with PRMT5, an arginine methyltransferase with the ability to catalyse the dimethylation of arginine 3 on the N-terminal tails of histones H2A and H4. BLIMP1 and PRMT5 are co-expressed in nascent germ cells indicating that the role of BLIMP1 in assuring germ cell identity and survival may depend on this complex (Ancelin et al., 2006).

After specification and during their migration to the developing gonads, germ cells undergo further epigenetic modification (Fig. 2). Initially, at around E8.0 germ cells and their somatic neighbours appear to be relatively epigenetically similar. Both exhibit Histone H3 Lysine 9 dimethylation (H3K9me2), which is associated with repressive chromatin, both contain DNA methylation patterns that are comparable and both have initiated Xchromosome inactivation (Tam et al., 1994; Seki et al., 2007; Sugimoto and Abe, 2007). However, these patterns begin to change specifically in germ cells from E8.0. DNA methylation levels become reduced, the maintenance DNA methyltransferase, DNMT1 (DNA methyltransferase 1) is transiently down regulated and the de-novo DNA methyltransferases DNMT3b and DNMT3a are suppressed or absent respectively (Seki et al., 2005; Yabuta et al., 2006; Seki et al., 2007). In addition, a recent study has shown bi-allelic expression of some genes that are not normally expressed from the inactive $\mathrm{X}$-chromosome at E7.75 (Sugimoto and Abe, 2007). Consistent with this, the critical regulator of $X$ inactivation, $X$ ist (Inactive $X$-specific transcript), is not expressed in approximately $5 \%$ of germ cells by E7.75 and is lost in all germ cells by $\mathrm{E} 10.5$.

Histone methylation patterns also change in early germ cells.
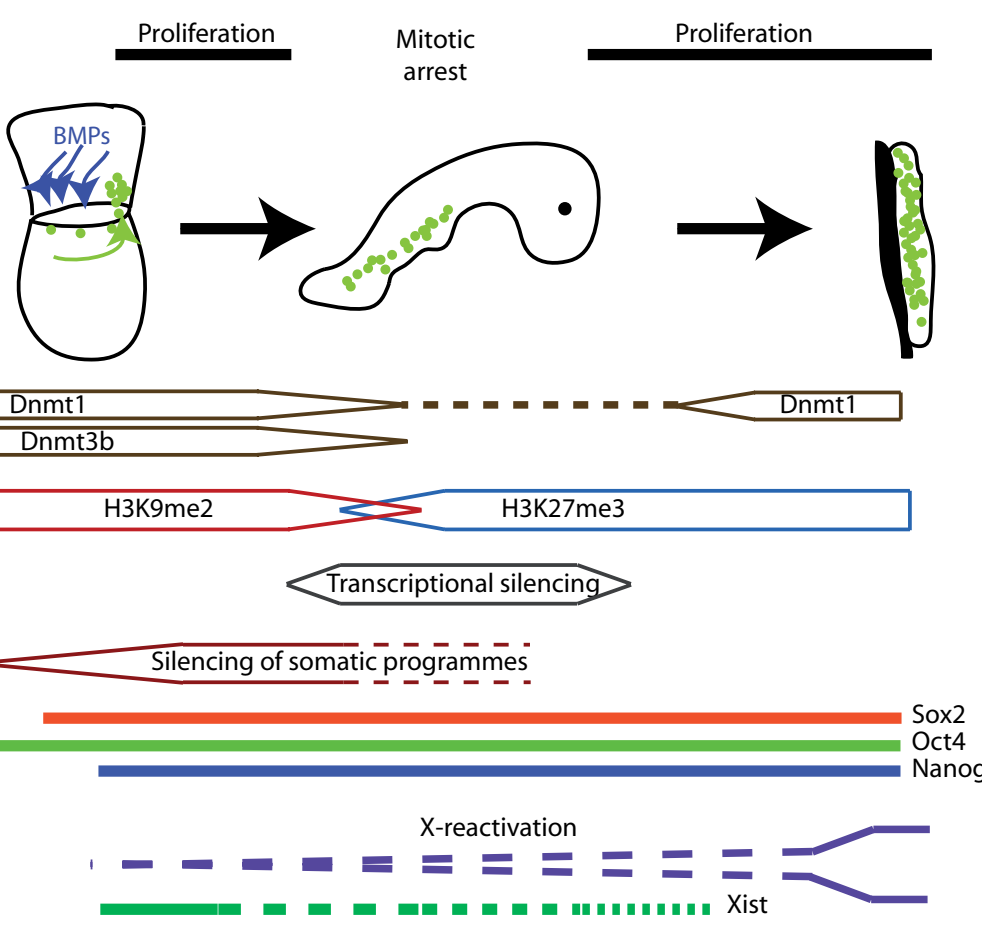

$\begin{array}{llll}\text { E7.5 } & \text { E8.5 } & \text { E9.5 } & \text { E11.5 }\end{array}$

Fig. 2. Mouse germ cell specification, epigenetic modification and affirmation of underlying totipotency. BMPs expressed in the extraembryonic ectoderm induce germ line development in a population of proximal epiblast cells. These cells activate expression of Fragilis, which is involved in homotypic adhesion of germ cells and their somatic neighbours. Blimp1, a SET domain containing transcriptional repressor is expressed in founding germ cells and is required to suppress genetic programs associated with somatic cell development, such as homoeobox genes. The nascent germ cells maintain or reactivate expression of core regulators of pluripotency, Oct4, Sox2 and Nanog. During migration germ cells undergo a transient period of G2 mitotic arrest, suspension of RNA polymerase dependent transcription and epigenetic reprogramming that establishes marks associated with underlying totipotency, such as H3K27 methylation. X-inactivation is initiated early with down-regulation of Xist and is completed in gonadal germ cells. During migration germ cells require various signals, including SCF that sustain their survival and proliferation until they enter the developing gonads. SDF is required to direct germ cell entry into the gonads. Germ cells that fail to enter the gonad lose expression of SCF and activate BCL dependent apoptotic pathways leading to cell death.

At approximately E8.5-9.0 there is an increase in H3K27me3 within germ cells, but not in the surrounding somatic cells. H3K27me3 is prominent in pluripotent embryonic stem cells. The histone methyltransferase, Ezh2 (Enhancer of Zeste 2), is required for establishing H3K27me3 modifications in ES cells and early embryos where it is essential for normal embryonic development (O'Carroll et al., 2001; Erhardt et al., 2003; Silva et al., 2003). EZH2 is strongly expressed in migrating germ cells indicating that EZH2 is likely to establish $\mathrm{H} 3 \mathrm{~K} 27$ me3 patterns within the developing germ cells at this time (Yabuta et al., 2006). Interestingly, the phase of epigenetic remodelling occurring in E8-9.5 germ cells coincides with transient G2 arrest in the cell cycle, repression of $R N A$ polymerase 2 transcription and germ cell specific repression of the histone methyl-transferase EHMT1 (euchromatic histone-lysine $\mathrm{N}$-methyltransferase 1, also known 
as G9a like protein GLP), which is required for the establishment of H3K9me2 methylation (Tachibana et al., 2005; Seki et al., 2007). Together, these experiments indicate that extensive epigenetic reprogramming occurs in migrating PGCs and that these epigenetic modifications are consistent with the maintenance of underlying genomic totipotency/pluripotency within the developing germ lineage (Seki et al., 2007; Surani et al., 2007) (Fig. 2).

Another unique feature of PGCs is their expression of genes, which either mark or are required by pluripotent cell types. The best understood of these genes is Pou5f1 / Oct4 (Pou domain class 5 transcription factor 1 or Octamer binding transcription factor 4), which encodes a POU domain containing transcription factor that is required to maintain pluripotency in pre-implantation embryos and embryonic stem (ES) cells (Nichols et al., 1998; Niwa et al., 2000). Oct4 is expressed during cleavage stages and becomes restricted to the pluripotent cells of the inner cell mass and epiblast. Oct4 expression is then maintained in the developing germ cells during their specification and throughout primordial germ cell development (Scholer et al., 1990; Yeom et al., 1996; Saitou et al., 2002; Yabuta et al., 2006). Continued Oct4 expression is required by primordial germ cells to maintain their survival, as Oct4 null germ cells undergo apoptosis (Kehler et al., 2004). In some contexts OCT4 functions with another transcription factor SOX2 (SRY BOX protein 2), which is up-regulated prior to Stella in nascent germ cells and is then maintained in PGCs (Yabuta et al., 2006). Sox2 is expressed in PGCs until after they have populated the genital ridges and been specified to develop along the spermatogenic or oogenic pathway. Sox2 expression is downregulated thereafter (Maldonado-Saldivia et al., 2007). A third important transcriptional regulator of pluripotency, Nanog, is also re-activated in nascent germ cells and maintained in PGCs in a pattern which is very similar to that observed for Sox2(Yamaguchi et al., 2005; Yabuta et al., 2006). Recent data shows that Nanog is required for maturation of $P G C s$ as they reach the genital ridge (Chambers et al., 2007). Although both NANOG and SOX2 are required for maintaining the inner cell mass in pre-implantation embryos and are important in pluripotency and self-renewal of ES cells (Avilion et al., 2003; Chambers et al., 2003; Mitsui et al., 2003), their functions in the germ line remain to be fully determined. However, on the basis of their key functions in early embryos and pluripotent ES cells it seems likely that OCT4, SOX2 and NANOG perform functions in maintaining underlying germ line totipotency/pluripotency and preventing differentiation of the developing germ cells (Fig. 2).

This conclusion is supported by the recent finding that ectopic expression of Oct4 and Sox2 in conjunction with the transcription factors KIf4 (Krupple like factor 4) and cMyc (myelocytomatosis oncogene), or Nanog and LIN28 (lin 28 homologue) can induce pluripotency in differentiated mouse and human fibroblasts (Takahashi and Yamanaka, 2006; Okita et al., 2007; Takahashi et al., 2007; Wernig et al., 2007; Yu et al., 2007). In mice these induced pluripotent cells are not only capable of contributing to all germ layers during development but can also form the germ line, indicating that these cells can gain genomic totipotency. Therefore, based on their role in initiating and controlling pluripotency in vivo and in vitro Oct4, Sox2 and Nanog can be viewed as "core regulators" of pluripotency.

In addition to Oct4, Sox2, and Nanog, PGCs activate several other markers of pluripotent cells including Esg1 (embryonic stem cell specific gene 1 also known as Dppa5), Dppa2 (developmental pluripotency associated gene 2) and Dppa4 during their migration and eventual entry into the developing gonads (Western et al., 2005; Tanaka et al., 2006; Yabuta et al., 2006; MaldonadoSaldivia et al., 2007). The function of these genes in PGCs (and in other pluripotent cells) is as yet unknown, however since Esg1 null mice are fertile, Esg1 is not essential for germ cell specification or survival (Tanaka et al., 2006). In addition, although Dppa2 and Dppa4 are not expressed in migratory germ cells prior to their entry into the gonads (Maldonado-Saldivia et al., 2007), it is possible to derive pluripotent embryonic germ (EG) cells from these migratory germ cells (Durcova-Hills et al., 2001). However, while Dppa2 and Dppa4 are not expressed in early PGCs, they appear to be up regulated during the derivation of $E G$ cells in which their expression is readily detected. Therefore, although Dppa2 and Dppa4 do not appear to be required for underlying pluripotency in PGCs, it remains possible that they are required for $E G$ cell formation.

Despite germ line re-acquisition of the transcriptional machinery underlying pluripotency, PGCs are not overtly pluripotent (McLaren, 2003; Durcova-Hills et al., 2006). This lack of pluripotency has been demonstrated using various assays. When PGCs are injected into mouse blastocysts or aggregated with morula they are incapable of differentiating or indeed of making any contribution to the host embryo. Similarly, they do not contribute to chimaeric ICM outgrowths in a comparable in vitro assay (McLaren, 2003; Durcova-Hills et al., 2006). Despite this it is possible to derive pluripotent EG cells from pre-migratory, migratory and gonadal PGCs (Matsui et al., 1992; Resnick et al., 1992; Labosky et al., 1994; Stewart et al., 1994; Tada et al., 1998; Durcova-Hills et al., 2001; Durcova-Hills et al., 2003; DurcovaHills et al., 2006). Pluripotent EG cells have also been derived from human PGCs (Shamblott et al., 1998). Consistent with this, when transplanted under the kidney capsule or grafted into adult testis, PGCs form pluripotent embryonal carcinoma (EC) cells that are regarded as the stem cells of teratocarcinoma (Stevens, 1967; Stevens, 1984; Matin, 2007). The formation of EG cells from PGCs is reliant on specific culture conditions and the presence of the growth factors SCF (Stem Cell Factor), FGF2 (Fibroblast Growth Factor 2 or basic FGF) and LIF (Leukemia Inhibitory Factor) (Matsui et al., 1992; Resnick et al., 1992; Durcova-Hills et al., 2006). EG cells are very similar to ES cells in that they are potentially immortal and pluripotent, however, they possess a more pronounced ability to reprogram certain epigenetic marks, which is best demonstrated in their erasure of genomic imprints (Tada et al., 1998; Tada et al., 2001). This quality reflects their germ line origin as $P G C$ s possess this activity in-vivo.

\section{Survival and proliferation: key aspects of early germ cell development}

While germ cells are considered mono-potential and can only develop into gametes, they must be programmed to generate a totipotent zygote. This involves a very specialised process of differentiation. To this end, germ cells must not only regulate underlying genomic totipotency and protect themselves from the inductive signals of various somatic lineages, they must also activate germ cell specific genetic programs which direct func- 
tions as diverse as cell migration, epigenetic erasure and establishment, spermatogenic or oogenic specification, meiosis and ultimately gamete production. To achieve these goals, specific genetic programs must be activated in germ cells at various stages of their development. Although the function of some of the genes required for some of these processes are understood, a great deal remains unknown. Two key aspects of germ cell biology that affect their ability to establish pluripotent cell populations are cell survival and proliferation.

Crucial to PGCs are the ligand SCF and its tyrosine kinase transmembrane receptor CKIT. The function of this pathway was initially discovered in the steel (which encodes SCF) and the dominant white spotting (which encodes CKIT) mouse mutants in which germ cells are lost during the migratory phase. SCF/CKIT signalling is required for proliferation and survival of germ cells and aberrant function of this pathway has been associated with abnormal proliferation and transformation of germ cells (Dolci et al., 1991; Godin and Wylie, 1991; Matsui et al., 1991; Dolci et al., 1993; Pesce et al., 1993; Donovan and de Miguel, 2003; Sakuma et al., 2003; McIntyre et al., 2005; Goddard et al., 2007). Two members of the NANOS family of RNA binding proteins, NANOS2 and NANOS3 are also required for survival of foetal germ cells (Tsuda et al., 2003; Suzuki et al., 2007). Nanos3 is expressed in migrating germ cells and functions to maintain early germ cell survival, at least partly through suppression of apoptosis (Suzuki et. al. 2008), while Nanos2 is male specifically expressed and required for survival and differentiation of gonadal germ cells (Suzuki et. al. 2007; Suzuki and Saga 2008). Another group of molecules, which affect PGC migration and proliferation are the fibroblast growth factors. Treatment of migrating germ cells in embryo slice cultures indicate that while FGF2 affects germ cell motility, FGF7 is required for germ cell survival and proliferation. Consistent with this, loss of function of the receptor for FGF7, FGFR2-3b results in reduced germ cell numbers (Takeuchi et al., 2005). In addition, BMPs regulate PGC numbers and motility in culture (Dudley et al., 2007; Ross et al., 2007). BMPs are also required for regulation of pluripotency in ES cells (Ying et al., 2003) and for recruitment of PGCs from the proximal epiblast during germ line specification (Lawson et al., 1999; Ying et al., 2001; Ying and Zhao, 2001; de Sousa Lopes et al., 2004). Several members of the interleukin family, including IL4 (Interleukin-4), IL6, IL11, IL2 and LIF have also been shown to enhance PGC survival and proliferation (De Felici and Dolci, 1991; Cheng et al., 1994; Cooke et al., 1996; Koshimizu et al., 1996; Eguizabal et al., 2007).

Clear associations have been made between the action of LIF, BMP4, SCF, and FGF2 and the acquisition and maintenance of pluripotency and self-renewal in ES cells and EG cells. For example the derivation of $E G$ cells requires a cocktail of SCF, FGF2 and LIF to facilitate the reprogramming of PGCs (which are not overtly pluripotent) to pluripotent EG cells (Matsui et al., 1992; Resnick et al., 1992). In this context it is of particular interest that other TGF $\beta$ (transforming growth factor $\beta$ ) family proteins such as ACTIVIN and NODAL are also involved in regulation of pluripotency in human ES cells and maintaining Oct4 and Nanog in the inner cell mass of the mouse epiblast (Vallier et al., 2004; Mesnard et al., 2006). However, whether these signalling molecules function in germ cell proliferation, survival and EG cell derivation is currently unknown. Finally, SDF (stromal cell derived factor 1 ) is required for directing PGC migration and has been implicated in promoting survival of migrating germ cells until they enter the gonad (Stebler et al., 2004).

Although maintaining germ cell survival is critical, it is sometimes necessary for the embryo to promote germ cell death. This occurs when germ cells lose their way due to loss of contact with migratory cues such as SDF (Stebler et al., 2004). These mislocalised germ cells can provide an undifferentiated germ cell substrate that can transform and establish extra-gonadal germ cell tumors. It has recently been shown that a key mechanism in eliminating these mis-localised germ cells is the down-regulation of SCF and the activation of intrinsic cell death that is mediated through the pro-apoptotic gene Bax (Stallock et al., 2003; Runyan et al., 2006). Finally, TGF $\beta 1$ and ACTIVIN limit PGC proliferation in various tissue culture systems (Godin and Wylie, 1991; Richards et al., 1999). Collectively, it is clear that the proliferation and survival of PGCs is strictly monitored and controlled during migration to the developing gonads and that failure of these mechanisms can lead to loss of germ cells and sterility or to extragonadal germ cell cancers.

\section{Gonadal germ cells}

By about E11 the developing germ cells have entered the developing genital ridge and will soon be subject to sex specific signalling processes. At this stage germ cells are sexually bipotential and can commit to either the spermatogenic pathway or the oogenic pathway (Adams and McLaren, 2002) (Fig. 1). This choice is strongly influenced by the somatic cells of the developing testis and ovary respectively (Adams and McLaren, 2002; McLaren, 2003; Bowles et al., 2006; Koubova et al., 2006). At E11.5 - E12.5 PGCs are also highly proliferative (Tam and Snow, 1981; Western et al., 2008) and can establish pluripotent EG lines in culture (Matsui et al., 1992; Labosky et al., 1994; Tada et al., 1998; Durcova-Hills et al., 2003; Durcova-Hills et al., 2006).

These features of PGCs begin to alter dramatically soon after E11.5. Between E11.5 and E12.5 germ cells in both male and female environments undergo extensive epigenetic reprogramming, that appears to be equivalent in both sexes. This involves widespread de-methylation of DNA at imprinted loci, single gene loci and the inactive X-chromosome but within IAP (Intracisternal A particle) elements and Line1 repeated elements, DNA methylation exhibits substantial resistance to erasure (Hajkova et al., 2002; Lane et al., 2003; Sato et al., 2003). Reprogramming of germ cells within the gonad occurs in the absence of nuclear DNMT3A and DNMT3B but in contrast to the re-programming of E8.0-9.5 PGCs (Seki et al., 2007) DNMT1 remains expressed in the nucleus of gonadal germ cells undergoing reprogramming (Hajkova et al., 2002). Reprogramming of germ cells during this phase is thought to be necessary for the developing germ cells to re-set their epigenetic status in preparation for the production of gametes. The gametes confer totipotency and supply crucial epigenetic information to the next generation, including parent of origin specific marks such as genomic imprints. This reprogramming activity is qualitatively different from that observed in ES cells and the oocyte in that EG cells erase genomic imprints, whereas at other developmental stages reprogramming leaves genomic imprints intact (Tada et al., 1997; Tada et al., 1998; Surani et al., 2007). After their erasure many of these critical 
epigenetic marks, such as genomic imprints, are re-established through the activity of DNMT3L and the de novo methyltransferase DNMT3A (Bourc'his et al., 2001; Hata et al., 2002; Bourc'his and Bestor, 2004; Kaneda et al., 2004; La Salle et al., 2004; Sakai et al., 2004; Webster et al., 2005; Kato et al., 2007; Lucifero et al., 2007; Shovlin et al., 2007). Establishment of appropriate epigenetic patterns subsequent to reprogramming is essential for normal development and in some cases (for example genomic imprints) these epigenetic patterns will be maintained in all somatic cells throughout the life of an individual.

Coincident with epigenetic reprogramming and germ cell exposure to the somatic environment of the developing gonad, the germ cells lose their ability to establish pluripotent EG cells in culture (Fig. 1). This change in developmental potential also coincides with the onset of germ cell sex determination, which in the male occurs between E11.5 and E12.5 (Adams and McLaren, 2002). Despite this, recent evidence indicates that it may be possible to generate pluripotent stem cells from spermatogonial stem cells in mouse and man indicating that underlying pluripotency may be re-accessed at this later stage of development (Kanatsu-Shinohara et al., 2004; Guan et al., 2006; Seydoux and Braun, 2006).
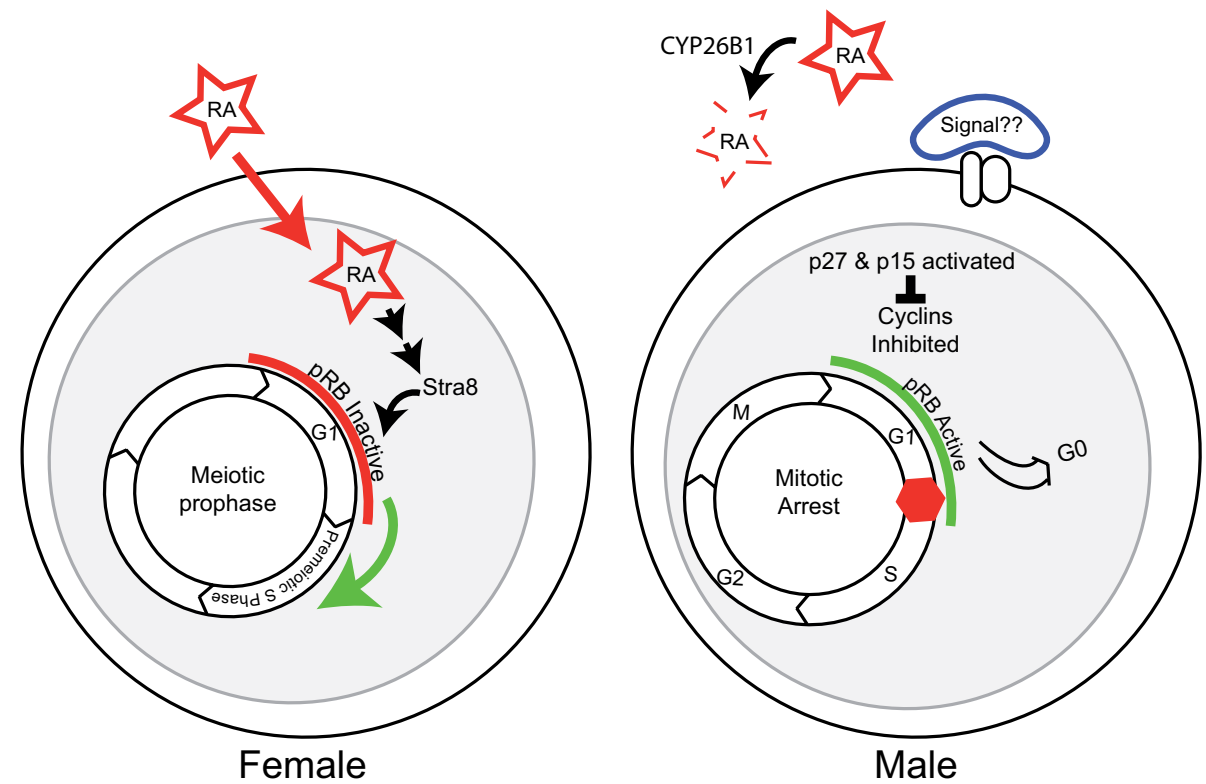

Fig. 3. Meiosis vs mitotic arrest in female and male foetal germ cells. After entering the gonad, germ cells are subject to sex specific inductive signals which originate in the somatic tissues and recruit germ cells to the male (spermatogenic) and female (oogenic) pathways. In females RA induces expression of Stra8, which is required for passage of germ cells through premeiotic $S$ phase. Consistent with their passage through G1-S-phase, female germ cells maintain expression of inactivated (hyper-phosphorylated pRB) during their entry into meiosis. In males, CYP26B1 metabolises RA preventing entry into meiosis and permitting male germ cell differentiation and cell cycle exit. An unknown signal induces expression of $p 27^{k i p 1}$ and $p 15^{I N K 4 b}$ at the initiation of mitotic arrest. Activity of the $E$ and $D$ type cyclins is presumably inhibited, $p R B$ is transiently activated (hypo-phosphorylated) and the germ cells arrest in GO.

\section{Germ cell sex determination}

Arrival of the germ cells into the developing gonads results in their exposure to inductive signals that promote either male or female development. Male sex determination is initiated by expression of the Y-chromosome gene, Sry (Sex Determining Region $Y$ chromosome), within the bi-potential somatic presupporting cells of the undifferentiated gonad (Gubbay et al., 1990; Sinclair et al., 1990; Koopman et al., 1991). Through a complex series of events the pre-supporting cells differentiate into Sertoli cells which are thought to act as a signalling centre to induce various aspects of testis development, including male germ cell development (Brennan and Capel, 2004; Wilhelm and Koopman, 2006; Wilhelm et al., 2007b). Organ culture experiments have shown that association of germ cells of either $X X$ or $X Y$ chromosomal constitution with the somatic cells of the developing testis results in germ cell commitment to spermatogenesis (McLaren and Southee, 1997; Adams and McLaren, 2002). Alternatively, if the same germ cells are associated with the somatic cells of the developing ovary they commit to oogenesis. This indicates that it is the surrounding environment, not the germ cells genetic content (i.e. $\mathrm{XX}$ or $\mathrm{XY}$ ) that primarily influences germ cell sex determination. This influence is presumably mediated through signalling between the surrounding somatic cells and the germ cells. Supporting this conclusion recent experiments have shown that Sdmg 1 (sexually dimorphic, expressed in male gonads 1 also known as Tmem 184a) is up regulated in male somatic cells during male germ cell commitment (Svingen et al., 2007; Best et al., 2008). Sdmg1 encodes a protein which functions in membrane trafficking and inhibition of this secretory pathway results in male to female germ cell sex reversal (Best et al., 2008). Despite this the signalling mechanisms that promote male or female germ cell commitment are poorly understood. From experiments where mouse $X Y$ and $X X$ germ cells of varying developmental age (E11.5, E12.5 and E13.5) were aggregated with developing ovary or testis respectively, it is apparent that male germ cells are irreversibly committed to spermatogenesis between E11.5 and $E 12.5$, while female male germ cells are irreversibly committed to oogenesis between E12.5 and E13.5 (Adams and McLaren, 2002) (Fig. 1).

Following commitment to oogenesis, female germ cells enter meiosis during foetal life. This contrasts with males, where meiosis is initiated post-natally. Recently it has been shown that retinoic acid (RA) stimulates activation of Stra8 (Stimulated by retinoic acid gene 8 ), which is required for germ cells to enter meiosis in both males and females (Baltus et al., 2006; Bowles et al., 2006; Koubova et al., 2006). Although some aspects have been debated (Best et al., 2008), currently the generally accepted model for initiation of meiosis suggests that RA levels within the foetal ovary and testis are strictly controlled, with the developing ovary being exposed to high levels, and the developing testis to low levels of RA. The repression of RA activity within the testis is achieved in large part through the action of the enzyme CYP26B1, which degrades RA (Bowles et al., 2006; Koubova et al., 2006). Interestingly, this reduction of RA in the developing testis has 
been associated with differentiation of male germ cells and their entry into mitotic arrest (Trautmann et al., 2008). By contrast the developing ovary does not express Cyp26B1, RA enters from the neighbouring mesonephric tissue and Stra8 expression is up regulated resulting in the entry of female germ cells into meiosis (Baltus et al., 2006; Bowles et al., 2006; Koubova et al., 2006). In males Stra8 is not up regulated until prior to entry of the germ cells into meiosis, which occurs post-natally. Interestingly, null mutation of Stra8 in mice results in accumulation of germ cells in the G1 phase of the cell cycle due to their failure to proceed through Sphase. Thus one role for STRA8 is to allow pre-meiotic DNA replication and therefore progression into meiotic prophase (Baltus et al., 2006) (Fig. 3). The mechanism underlying this activity is yet to be investigated.

Although this data shows that RA activation of Stra8 is key for pre-meiotic DNA replication and progression into meiosis in males and females, it is not clear that the combination of these factors is required for commitment of the germ cells to oogenesis. It is possible that commitment is equivalent to induction of Stra8, or that unknown molecular processes lead to female germ line commitment and Stra8 is activated slightly later. This is currently difficult to resolve in the mouse model as commitment of female germ cells to oogenesis coincides with the function of STRA8 in inducing pre-meiotic DNA synthesis and germ cell entry into meiosis. However, two circumstantial observations indicate that pre-meiotic DNA synthesis may not equal female germ cell sex determination. First, progression of female germ cells into meiosis in other species appears to be delayed with respect to the somatic sex-determining period (for example in chickens, rabbits, humans or sheep; (Byskov, 1986; Bendsen et al., 2006) C. Smith personal communication). Such species may provide opportunities to study female germ cell sex determination without the complicating process of immediate entry into meiosis. Second, in males RA and STRA8 are required for entry into meiosis during post-natal development, indicating that control of pre-meiotic Sphase entry is conserved and controlled by STRA8 in both males and females. If STRA8 is required for female germ cell commitment it must regulate both specification and pre-meiotic S-phase entry or these two events must be biologically equivalent. A simpler explanation may be that STRA8 regulates pre-meiotic Sphase commitment in males and females, and that this follows commitment of male or female germ cells, which is regulated by unknown mechanisms respectively.

In males germ cells are protected from exposure to RA, and therefore entry into meiosis, through the metabolism of RA by CYP26B1 (Bowles et al., 2006; Koubova et al., 2006). At the same time the germ cells are subject to inductive signals that promote their commitment to the spermatogenic pathway and entry into mitotic arrest. The signals promoting these developmental choices are as yet undefined, however, commitment of germ cells to spermatogenesis in mice rapidly follows somatic sex determination, which involves commitment of the Sertoli cell lineage and organization of the germ cells within the developing testis cords. At this developmental stage the expression of the Fibroblast growth factor family member Fgf9 is required for somatic sex determination and germ cell survival in males (DiNapoli et al., 2006). Similarly a member of the prostaglandin family prostaglandin D2 is male specifically expressed in somatic and germ cells and plays a role in Sertoli cell recruitment and differentiation
(Adams and McLaren, 2002; Wilhelm et al., 2005; Wilhelm et al., 2007a). The potential role of these signalling molecules to promote male development of the germ cell lineage is as yet unknown.

In mice, soon after the germ cells commit to the spermatogenic pathway they change from a highly proliferative state and enter mitotic arrest over a period of approximately twenty-four hours. Initially in E11.5-E12.5 male mouse embryos, gonadal germ cells are highly proliferative (Tam and Snow, 1981; Western et al., 2008). However, various reports show that one day later (E13.5) the germ cells are proceeding through or have completed mitotic arrest (Hilscher et al., 1974, McLaren, 1984; Adams and McLaren, 2002; Western et al., 2008), while other studies indicate that germ cells are not quiescent until as late as E16.5 (Sapsford, 1962; Vergouwen et al., 1991). A recent study has analysed this progression in more detail by employing flow cytometry to examine the cell cycle state of germ cells prior to, during and after their entry into quiescence (Western et al., 2008). This study also compared inbred with outbred mouse strains and a cross of the two. In C57BL6 inbred mice, germ cells enter quiescence between E13.5 and E14.5, a day after seminiferous cord formation, while in the outbred strain, CD1, germ cells enter quiescence between E12.5 and E13.5, immediately after cord formation. Interestingly, the cross of these strains showed that germ cells enter quiescence between E13 and E14, at about the midpoint in time between the inbred and outbred strains (Western et al., 2008; P. Western, D. Miles, J. van den Bergen and A. Sinclair unpublished data). This data indicates that mitotic arrest in mice is a relatively, (but not entirely) synchronised event that occurs in approximately 24-36 hours between E12.5 and E14.5, that this progression is strain dependent and that in some strains (eg $\mathrm{C} 57 \mathrm{Bl6}$ ) there is a lag of up to 48 hours between the formation of cords (indicating somatic sex determination has occurred) and the final S-phase progression prior to mitotic arrest of the germ cells (Fig. 4).

On the basis of this data it is tempting to speculate that commitment of germ cells to spermatogenesis and their entry into mitotic arrest may be regulated separately at the molecular level. For example the signalling mechanisms responsible for initiating male commitment of the germ cells may be different from the molecular signals/pathways initiating mitotic arrest. This hypothesis is supported by observations in other vertebrate species. For example, in humans mitotic arrest of germ cells occurs considerably later than somatic sex determination and cord formation (and probably germ cell sex determination) in the foetal testis (Bendsen et al., 2003; Gaskell et al., 2004). Human germ cells are enclosed within the testis cords during the seventh week of development and presumably undergo spermatogenic lineage commitment at about this time. Germ cells proliferate from a population of approximately 3000 at this time to 30000 by week nine and apparently retain proliferative activity until about week eighteen (Bendsen et al., 2003; Gaskell et al., 2004). During this time accumulating numbers of germ cells appear to exit the cell cycle in a relatively unsynchronised manner (Gaskell et al., 2004).

The molecular mechanisms underlying mitotic arrest are poorly understood. Independent reports have shown that particular cell cycle proteins are expressed in cycling mouse germ cells and not in quiescent germ cells, or vice versa. For example Cyclin D3 was detected, but Cyclin D2 and the Cyclin-Cdk inhibitor, p27 ${ }^{\mathrm{Kip} 1}$ were 
not detected in germ cells at E14.5. By contrast Cyclin D2, Cyclin D3 and p27 Kip1 were present in quiescent germ cells at E17.5 (Beumer et al., 1999; Beumer et al., 2000). Recent work has examined the progress of germ cells into quiescence by directly examining all the members of the G1 cyclins, the CIP/KIP and INK4 inhibitors, which regulate the activity G1-S cyclin complexes, and the pocket proteins that control the check-point for G1-S phase transition. By analysing pure germ cell populations prior to, during and after mitotic arrest, this work has shown that the progression of germ cells into quiescence involves the regulation of a subset of cell cycle proteins that control G1-S phase transition. This includes the up regulation of the Cyclin-Cdk inhibitors p2 $7^{\mathrm{kip} 1}, \mathrm{p} 15^{\mathrm{INK} 4 \mathrm{~b}}$ and $\mathrm{p} 16^{\mathrm{INK} 4 \mathrm{a}}$, suppression of Cyclin E1 and $\mathrm{E} 2$ and regulation of the phosphorylation state of the G1-S phase checkpoint protein pRB (Western et al., 2008). pRB is initially hyper-phosphorylated (inactive) in highly cycling germ cells at E12.5, but then becomes de-phosphorylated (activated) in arresting germ cells. Its expression is then down-regulated and eventually lost in quiescent germ cells. Therefore it appears that pRB is activated only transiently during the entry of germ cells into mitotic arrest and this activity is likely to prevent G1-S phase transition at this stage. However, since pRB is degraded after $\mathrm{E} 14.5$, its activity does not appear to be required to maintain quiescence in germ cells (Fig. 4).

Interestingly, in human foetal germ cells pRB expression was absent in the majority of testicular germ cells at 28 weeks, while it was expressed in adult testis, but not in testicular germ cell tumors (TGCT) (Bartkova et al., 2003). This indicates that pRB is lost in TGCT. pRB is absent in quiescent mouse germ cells after E15.5. In humans germ cells have apparently exited the cell cycle after 18 weeks, and therefore in week 28 testes pRB expression may be repressed due to quiescence, as it is in mouse. This would be consistent if the biology of mouse and human male germ cell development is similar with respect to pRB function. Indeed, supporting the notion that mitotic arrest in human and mouse germ cells is similar $\mathrm{p} 15^{\mathrm{INK} 4 \mathrm{~b}}$ and $\mathrm{p} 16^{\mathrm{INK} 4 \mathrm{a}}$ are present in quiescent mouse germ cells (Western et al., 2008) and variably detected human foetal male testicular germ cells at 28 weeks. However, the role of $\mathrm{pRB}$ in mitotic arrest of human germ cells remains undefined. Interestingly, both $\mathrm{pRB}$ and $\mathrm{p} 16^{\mathrm{INK} 4 \mathrm{a}}$ are both absent in TGCTs, although $\mathrm{p} 15^{\mathrm{INK} 4 \mathrm{~b}}$ expression was widely detected (Bartkova et al., 2003)

Choice between meiosis and mitotic arrest in female and male foetal germ cells provides a unique juxtaposition of two alternative paths for cell cycle progression. As discussed earlier, entry into pre-meiotic S-phase is dependent on Stra8 (Baltus et al., 2006). However, neither progression through mitotic S-phase or the arrest of foetal male germ cells in G0 is dependent on Stra8. Despite this, RA and Stra8 expression can induce pre-meiotic Sphase in foetal male germ cells, indicating that RA and STRA8 are sufficient to promote premature meiotic entry. The progression of germ cells into mitotic arrest in males or meiosis in females are also associated with quite different regulation patterns of the G1$S$ phase check point protein pRB. In males pRB becomes dephosphorylated and presumably activated, while in females this activation is apparently robustly blocked and pRB becomes hyper-phosphorylated (Western et al., 2008; P. Western, D. Miles, J. van den Bergen and A. Sinclair unpublished data). This raises the interesting possibility that the choice of terminal differentiation and entry into meiosis or entry into the transient and nonterminal period of mitotic arrest could be mediated by controlling pRB activity (Fig. 3). Since STRA8 activity is required for premeiotic S-phase entry and pRB is present but apparently inactive during this process, it is also tempting to speculate that STRA8 may play a role in regulating this developmental choice by influencing pRB activity.

At the entry of male germ cells into mitotic arrest there are many changes, which indicate that although these cells are not actively dividing, many other developmental processes occur during quiescence. These changes include aspects of epigenetic programming, regulation of pluripotency, cell signalling and nuclear import/export, sex specific development and regulation of gene and protein expression. DNA methylation at imprinted loci is regulated in quiescent germ cells through the activity of DNMT3A and DNMT3L which are both up regulated early during male germ cell differentiation and are required for establishing imprints during this developmental phase (Bourc'his et al., 2001; Hata et al., 2002; Bourc'his and Bestor, 2004; Kaneda et al., 2004; Sakai et al., 2004; Webster et al., 2005; Kato et al., 2007; Lucifero et al., 2007; Shovlin et al., 2007). Proteins such as, NANOS2, a member

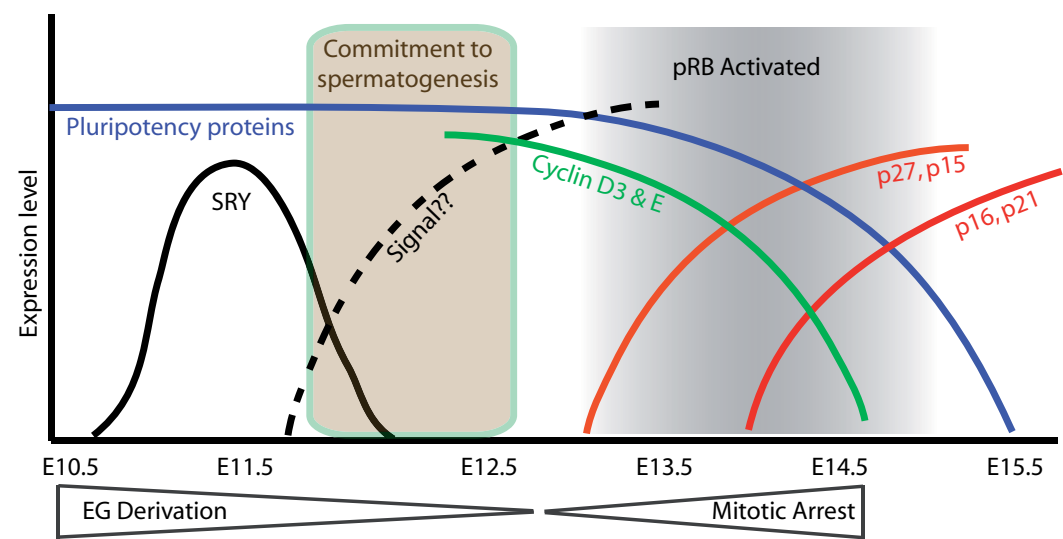

Fig. 4. Male commitment and early differentiation of male foetal germ cells. In mice male sex determination is initiated by SRY, which commits the somatic supporting cells to Sertoli cell development. Germ cells enter the gonad at approximately E10.5. Between E10.5 and E12.5 germ cells strongly express the core regulators of pluripotency and can establish EG colonies. Between E11.5 and E12.5 the germ cells are subject to inductive signals, apparently originating from the developing Sertoli cells, which recruit germ cells to the male (spermatogenic) pathway. The molecular processes leading to commitment of germ cells to the male pathway are not understood. After E12.5 male germ cells can no longer establish pluripotent $E G$ colonies and soon after down regulate the core regulators of pluripotency OCT4, NANOG and SOX2. At E11.5 and E12.5 the germ cells are highly proliferative and express inactive hyper-phosphorylated pRB, Cyclins E1, E2 and D3 but not the INK4 and CIP/KIP inhibitors p1 $5^{I N K 4 b}$ and $p 27^{k i p 1}$. By E13.5 mitotic arrest has been initiated and is essentially complete by E14.5. At the onset of mitotic arrest (E13.5) p1 $15^{I N K 4 b}$ and $p 27^{k i p 1}$ are strongly up regulated and presumably inhibit the E and D-type cyclin/cdk complexes. The cyclins are down regulated and $p R B$ becomes de-phosphorylated and present in its active hypo-phosphorylated form. During the later stages of mitotic arrest (E14.5 -E15.5), the INK4 and CIP/KIP inhibitors $p 16^{I N K 4 a}, p 21^{c i p 1}$ and $p 57^{k i p 2}$ are up regulated and pRB becomes down regulated. 
of the NANOS RNA binding protein subfamily, are also up regulated in arresting male germ cells and are required for further germ cell development (Tsuda et al., 2003; Suzuki et al., 2007; Suzuki and Saga, 2008; Suzuki et al., 2008). Nuclear import and cell signalling pathways are regulated in quiescent germ cells (Hogarth et al., 2005; Hogarth et al., 2007). GCNA (germ cell nuclear antigen) decorates germ cells after they enter the gonad but relocates from the cytoplasm to the germ cell nucleus during quiescence ( $P$. Western, D. Miles, J. van den Bergen and A. Sinclair unpublished data). Transcriptional profiling in purified germ cells indicates that many genes are activated and suppressed during the early stages of male germ cell development, suggesting that substantial changes occur in the differentiation status of these cells during this early differentiation down the spermatogenic lineage ( $P$. Western, D. Miles, J. van den Bergen and $A$. Sinclair unpublished data). These changes are also reflected in the loss of potential for germ cells to establish pluripotent EG colonies, which occurs after E12.5 by which time they have committed to male development. Finally, between E12.5-E15.5 genes that control pluripotency are down regulated in male germ cells (Yamaguchi et al., 2005; Maldonado-Saldivia et al., 2007; P. Western, D. Miles, J. van den Bergen and A. Sinclair unpublished data). Combined, these observations indicate that far from being a period of inactivity, many important developmental changes occur in quiescent male germ cells. This is also the case for male and female migratory germ cells, in which extensive epigenetic reprogramming occurs during the transient G2 cell cycle arrest that occurs at approximately E8.5 (Seki et al., 2007).

\section{Control of pluripotency in gonadal germ cells}

Commitment of germ cells to the male lineage is associated with the down regulation of the core pluripotent regulators, Oct4, Sox2 and Nanog and other pluripotent markers such as Dppa2, Esg 1 and SSEA1 (stage specific embryonic antigen 1) (Yamaguchi et al., 2005; Maldonado-Saldivia et al., 2007; P. Western, D. Miles, J. van den Bergen and A. Sinclair unpublished data) (Fig. 4). In addition, the antigenic marker of pluripotency $4 \mathrm{C} 9$ is also lost (Kimura et al., 2003). Control of the pluripotent regulatory network in the early male germ cell lineage involves both the regulation of transcription (for some genes) and regulation of translation (for other genes) (Maldonado-Saldivia et al., 2007; P. Western, D. Miles, J. van den Bergen and A. Sinclair unpublished data). Down regulation of pluripotent markers has also been observed during the early differentiation of foetal human germ cells (Gaskell et al., 2004). Suppression of pluripotency appears to be more stringently regulated in germ cells of the early female germ cell lineage than in males as at commitment to oogenesis and entry into meiotic arrest Oct4, Nanog, Sox2 and Dppa2 are all stringently suppressed at the transcriptional level in females, while in males this transcriptional control is more limited ( $P$. Western, D. Miles, J. van den Bergen and A. Sinclair unpublished data). The role of the pluripotent regulators in the developing germ line is not understood. However, based on their role in pluripotent stem cells, it has been assumed that the core transcriptional regulators of pluripotency, Oct4, Sox2 and Nanog are required to maintain pluripotent potential in developing germ cells. This hypothesis has yet to be tested experimentally. Since the normal function of these genes in pluripotent stem cells, is to block differentiation and maintain self-renewal, it has been proposed that the suppression of pluripotent regulators may be required to allow appropriate differentiation and cell cycle exit during the early stages of male germ cell development (Maldonado-Saldivia et al., 2007). In this context it is particularly interesting that, amongst others, the core regulator of pluripotency, Oct4, is re-activated in germ cell derived testis cancers (Gaskell et al., 2004; Rajpert-De Meyts et al., 2004).

\section{Germ cell cancer}

Since this review is focussed on foetal germ cell development, I will not attempt a detailed review of the formation of germ cell cancer here. Amongst others, Rejpert-deMeyts et. al. 2003; Almstrup et. al. 2005; Cools et. al. 2007; Oosterhuis and Looijenga (2005) and Reuter (2005) provide more detailed reviews of the topic of germ cell cancers (Rajpert-De Meyts et al., 2003; Almstrup et al., 2005; Oosterhuis and Looijenga, 2005; Reuter, 2005; Cools et al., 2006). However, it is relevant to briefly introduce germ cell derived cancers and discuss this topic in the context of early germ cell development. Testicular germ cell tumours (TGCT) in neonates, children and young males are derived from germ cells exhibiting early developmental characteristics. Type1 TGCTs occur with low incidence in neonates and children, and are thought to be derived from relatively undifferentiated PGCs based on their expression of genes active in PGCs and the limited amount of DNA methylation erasure that has occurred at imprinted loci. These tumours occur in the testis and ovary as well as various extra-gonadal regions within the body. Type 1 TGCTs most closely resemble those of teratomas that are found in mice. In humans these tumours are either classified as teratomas or yolk sac tumours. Teratomas are usually chromosomally normal, while yolk sac tumours are aneuploid. By contrast to the type 1 TGCTs, type 2 TGCTs are aneuploid with well characterised chromosomal aberrations commonly occurring, particularly duplication of $12 p$.

Type 2 TGCTs are more complex than Type 1 TGCTs, however type 2 TGCTs are also believed to be formed from PGCs or gonocytes. The majority of Type 2 TGCTs form in 15-40 year old males from germ cells that are located within the testis tubules and which retain foetal germ cell characteristics. These germ cells are the precursor cells for TGCT and are described as Carcinoma In situ (CIS) or Intra-tubular germ cell neoplasia unclassified (ITGCNU) (Skakkebaek et al., 2001; Rajpert-De Meyts et al., 2003; Oosterhuis and Looijenga, 2005). During the progression of cancer these cells initially form seminoma and on occasion progress to non-seminoma which include embryonal carcinoma that is thought to represent the neoplastic equivalent of embryonic germ cells. Consistent with this origin CIS, seminoma and embryonal carcinoma all exhibit aberrant reactivation or maintenance of OCT4 expression (Looijenga et al., 2003; Rajpert-De Meyts et al., 2004) and express other markers of pluripotency such as Nanog (Hoei-Hansen et al., 2005; Hart et al., 2005) and specific microRNAs (Voorhoeve et al., 2007). Normally in humans expression of Oct4 is repressed in the developing germ line after about 18 weeks (Gaskell et al., 2004; Rajpert-De Meyts et al., 2004). The activation of Oct4 in TGCT cells is not understood and whether or not it has a role in driving oncogenesis in germ cells is 
yet to be determined. However, expression of Oct4 and other markers of pluripotent cell lineages is typical of CIS, Seminoma and Embryonal carcinoma and reflects functional pluripotency that is often associated with EC.

Progression of $\mathrm{CIS}$ to the more advanced stages of seminoma and non-seminoma is poorly understood at the molecular level. Seminoma is characterised by the retained expression of markers of foetal germ cells such as OCT4, cKIT and TNAP. cKIT is a tyrosine type III receptor to which SCF binds and mediates functions required for survival and migration of PGCs and enhanced EG cell formation in vitro. In humans, foetal germ cells coexpress CKIT, TNAP and OCT4 until several weeks after testis cord formation indicating that these cells are relatively undifferentiated (Gaskell et al., 2004; Rajpert-De Meyts et al., 2004). During neoplastic progression germ cells take on the overtly pluripotent characteristics typical of embryonal carcinoma cells that act as stem cells within the germ cell tumour. This progression involves reprogramming steps, which convert the non-pluripotent germ cells through CIS to seminoma or embryonal carcinoma (RajpertDe Meyts et al., 2003; Oosterhuis and Looijenga, 2005). This process exhibits some similarities to the formation of pluripotent EG cells from their non-pluripotent PGC precursors.

Occurrence of germ cell tumours is also associated with a loss of contact of the germ cells with their micro-environment. One example of this is the formation of extra gonadal germ cell tumours, which are thought to be derived from PGCs and which often activate germ cell markers and regulators of pluripotency such as Oct4 (Oosterhuis et al., 2007). Similarly when differentiation of the somatic component of the developing testis is abnormal, formation of germ cell tumours can ensue. These developmental anomalies include androgen insensitivity syndrome, testicular dysgenesis (where the somatic component of testis development does not form appropriately), cryptorchidism and testicular atrophy all of which commonly lead to formation of germ cell tumours (Skakkebaek et al., 2001). The formation of germ cell tumours in these cases indicate that in order to differentiate appropriately along the spermatogenic pathway, germ cells must reside within the correct micro-environment and presumably receive and interpret the appropriate differentiative cues. In the absence of these regulatory mechanisms, the germ cells may maintain or re-activate expression of foetal germ cell markers such as Oct4 and other regulators of pluripotency and ultimately if the appropriate conditions exist, they will form germ cell tumours.

Germ cell derived tumours are extremely rare in most strains of mice. However, within mice of the inbred 129sv strain teratoma occurs spontaneously at a frequency of $1-5 \%$. This indicates that strong genetic and/or epigenetic components underlie the formation of germ cell tumours in mice and that mice of the 129sv strain carry modifier alleles that confer this susceptibility. More than 30 years ago a breeding program aimed at identifying germ cell tumour susceptibility genes was performed. This work resulted in the identification of the ter mutant which exhibits loss of PGCs in a range of inbred and outbred mouse strains and PGC loss combined with strong susceptibility to teratoma in the 129sv strain (Stevens, 1973). EC cells, derived from transformed germ cells, have been observed in 129sv or in $129^{\text {ter }}$ mice as early as E15 or E16 respectively (Noguchi and Stevens, 1982; Rivers and Hamilton, 1986) indicating that teratoma in these mice arise from very early male germ cells.
Recently the gene that contains the ter mutation was identified as Dnd1, which encodes a protein containing an RRM domain that likely binds target RNAs and perhaps DNA (Youngren et al., 2005). The DND1 protein shares homology with APOBEC1, a protein known to function in RNA editing. 129 male mice heterozygous for ter exhibit a $17 \%$ incidence of TGCT, which is significantly increased on the normal incidence of up to $5 \%$ in this strain. This incidence increases substantially to $95 \%$ when homozygous ter mutants occur on the 129sv background (Youngren et al., 2005). It has been hypothesised that the difference in incidence of teratoma between 129sv and other strains may be due to differences in survival of some DND1 null PGCs in this strain allowing them to populate the developing testis and then subsequently transform under the influence of testicular growth factors (Youngren et al., 2005; Matin, 2007). Recently a very interesting study in fish has shown that DND1 inhibits access for miRNAs (micro RNAs) to the three prime untranslated region (and therefore stabilises or allows translation) of the mRNA encoding the germ cell survival factor NANOS and the cell cycle regulator p27 ${ }^{\text {kip1 }}$ (Kedde et al., 2007). miRNAs can regulate cell cycle progression through CIP/KIP family members, particularly p27 kip1 (le Sage et al., 2007; Voorhoeve et al., 2007). Whether DND1 proteins bind p27 or Nanos mRNA to enhance their translation in mouse foetal male germ cells is yet to be determined, however, p2 $7^{\mathrm{kip} 1}$ and NANOS 2 have been implicated in cell cycle regulation and survival/differentiation respectively (Suzuki and Saga, 2008; Western et al., 2008) (Fig. 5). Clearly, the interactions underlying teratoma formation are complex and the gonadal environment (e.g. production of growth factors) and germ cell susceptibility factors in 129sv differ from those of other strains thus allowing more efficient transformation and teratoma formation.

Other notable tumour suppressor genes that have been linked with teratoma formation in mice are the regulator of cell cycle and apoptosis, p53 (Harvey et al., 1993) and the regulator of cell signalling, PTEN (phosphatase and tensin homolog from chromosome 10) (Kimura et al., 2003). Interestingly, p53 has been associated in humans with TGCTs and is located within chromosome $12 p$, chromosomal anomalies of which commonly occur in TGCT (Donovan and de Miguel, 2003). Conditional deletion of PTEN in germ cells leads to over-proliferation of foetal germ cells in males, formation of testicular teratoma and enhanced EG cell production. PTEN is a phosphatase which functions to block PIP3 (phosphatidylinositol triphosphate) signalling through PIP3 dephosphorylation. The loss of sustained differentiation in PTEN null germ cells and their propensity to form teratoma indicates that PIP3 signalling is required for the maintenance of the immature state of germ cells and underlies their ability to form EG cells. However, the increase in EG colony formation in PTEN null mice is still reliant on the growth factors LIF and FGF2 (Kimura et al., 2003) indicating that activation of PIP3 signalling by these factors is important for germ cell reprogramming and EG formation (Fig. 5). Although PTEN null germ cells initially express markers such as Mvh that indicate acquisition of characteristics typical of differentiating gonadal germ cells, expression of this marker is lost from E16.5 in PTEN null germ cells which then go on to form teratomas (Kimura et al., 2003). Therefore it appears that PTEN null germ cells initiate germ lineage differentiation, but subsequently the germ cells de-differentiate and form teratoma. Since germ cells in the PTEN mutant mice initially appear more differ- 


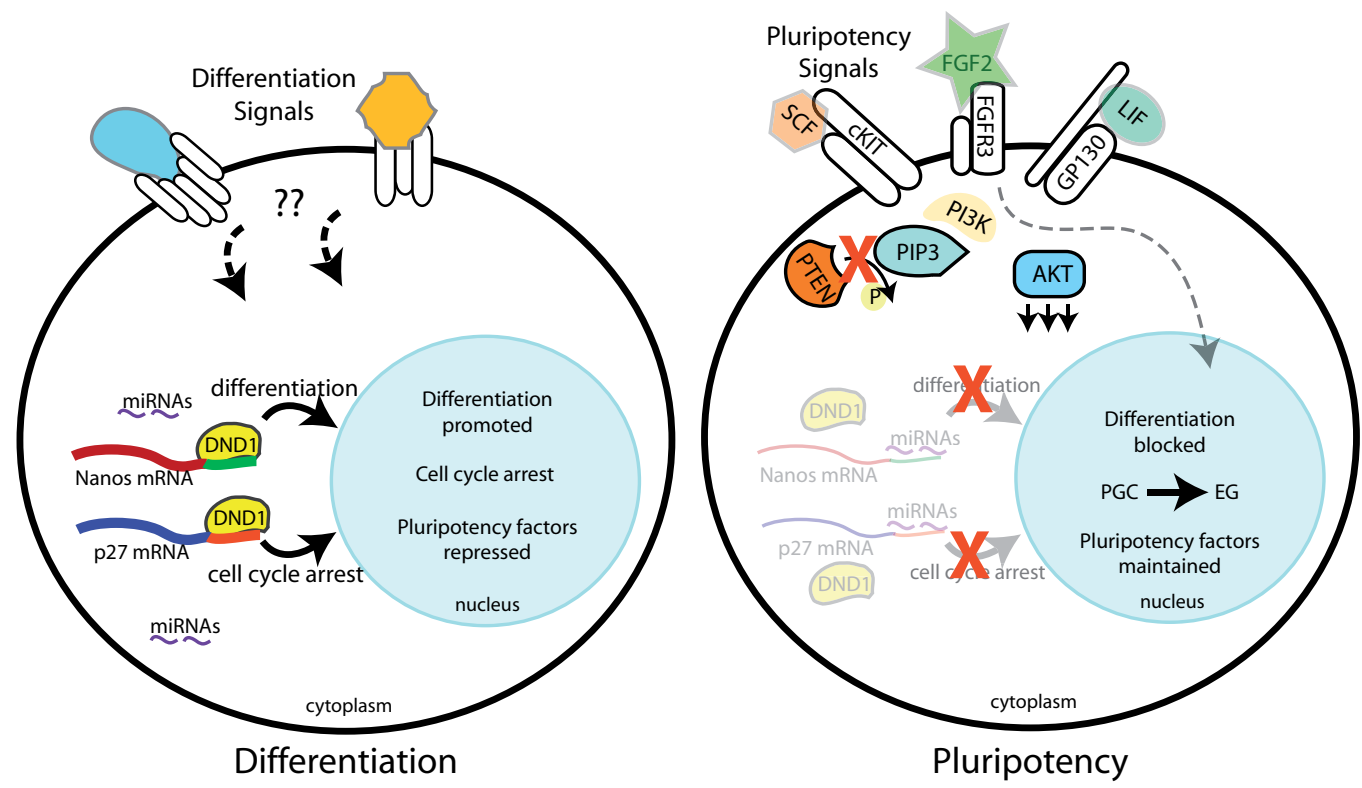

Fig. 5. Hypothetical model of male germ cell development: differentiation vs pluripotency. In the appropriate male cellular and molecular environment PGCs normally differentiate along the spermatogenic lineage, which involves cell cycle arrest and suppression of the core regulators of pluripotency, OCT4, NANOG and SOX2. DND1 is required for survival and may disrupt miRNA inhibition of mRNAs that regulate cell cycle (eg p27kip1), survival and differentiation (eg Nanos 2/3). However, if differentiation is inhibited reprogramming of PGCs to pluripotency may result. Formation of pluripotent EG cells from PGCs in vitro requires growth factors such as FGF2 (or FGF5, 9 or 10), SCF and LIF. During $E G$ formation this reprogramming process depends on an initial twenty-four hour exposure of the germ cells to FGF2, after which FGF2 is no longer required. FGF2 initiates nuclear localisation of the FGF receptor, FGFR3 and apparent reprogramming to pluripotency. Formation of pluripotent germ cells involves silencing of germ cell differentiation factors, maintenance of cell cycle and maintenance of the core regulators of pluripotency, OCT4, NANOG and SOX2, which are expressed by PGCs. Mutation of the PIP3 phosphatase PTEN leads to enhanced EG cell formation after E12.5, that is reliant on FGF2, SCF and LIF signalling and to germ cell cancers in vivo, indicating that pluripotent cell formation involves the PIP3/PTEN signalling pathway. Hyperactivation of AKT also promotes EG formation. Mutation of Dnd1, which encodes an RNA binding protein, leads to enhanced EG formation in vitro and germ cell cancer formation in vivo.

entiated than those in the DND1 mutants it is possible that PTEN may either result in a weaker or later block of germ cell differentiation in the differentiating testis than does loss of DND1 activity or that the small numbers of germ cells in the Dnd1 (ter) mutant allow them to be more potently transformed at the onset of male germ cell development than does the PTEN mutation.

It has been observed that in $129^{\text {ter }}$ mice, teratoma foci can occur in the testis cords of E15.5 mice (Noguchi and Stevens, 1982) and that the environment of the early differentiating testis influences the incidence of teratoma. When E12.5 genital ridges were transplanted to adult testes the incidence of teratoma was high, but this incidence became substantially and progressively lower when E13.5 and E14.5 genital ridges were transplanted the same way (Stevens, 1964; Stevens, 1966). This is supported by the observation that when E12.5 germ cells were combined with E12.5 somatic cells and transplanted to adult testes the incidence of teratoma was high, but when E12.5 germ cells are combined with E15.5 or E17.5 somatic cells and transplanted into adult testes the incidence of teratoma was low (Regenass et al., 1982), implying that the E12.5 somatic cells produce factors that can promote teratoma formation. However this transforming activity is effective only on germ cells from a tumour susceptible background, as germ cells from non-susceptible strains did not form tumours. It therefore appears that the germ cell transforming activity in developing mouse gonads acts more potently at the stage of male germ cell specification, when germ cells are still proliferative and just prior to the period during which pluripotency markers are suppressed. This occurs in strains that are susceptible to teratoma formation and exhibit relatively easy access to pluripotency (eg 129sv).

Interestingly, in mice of the 129sv strain it was shown that male germ cell proliferation was maintained longer and the incidence of teratomas increased in some lines (Noguchi and Stevens, 1982). Thus it appears that differentiation down the spermatogenic pathway and cell cycle exit reduce the potential of germ cells to establish teratoma. Differences have also been observed in the timing of germ cell mitotic arrest in 129sv and C57BL6 mice compared to outbred CD1 mice (Western et al., 2008; P. Western, D. Miles, J. van den Bergen, R. Ralli, A. Sinclair unpublished data). The variability of timing in mitotic arrest appears likely to be due to differences in response of the germ cells to the male gonadal environment or to the potency of the differentiative cues supplied by the gonadal environment to the germ cells. This possibility is of interest as the 129 sv and C57B/6 strains represent the most permissive strains for the derivation of ES cells, respectively (Brook and Gardner, 1997; Buehr and Smith, 2003) and the most commonly used strains for EG cell derivation (Matsui et al., 1992; Resnick et al., 1992; Labosky et al., 1994; Stewart et al., 1994; Durcova-Hills et al., 2001; Durcova-Hills et al., 2003) indicating that these strains have a greater ability to access pluripotency in the inner cell mass and in germ cells.

\section{Re-accessing pluripotency: Embryonic Germ Cells}

The influence of molecular mechanisms (for example signalling, epigenetic programming) on the formation of teratoma in mice is not understood. However, formation of teratoma from untransformed germ cell precursors leads to some similar outcomes (pluripotency, proliferation, de-differentiation) as the reprogramming of germ cells to EG cells. Therefore I will briefly discuss some of the current understanding of EG cell formation in this context. It is possible to derive EG cells with reasonably high 
frequency from the 129sv strain. The ability of germ cells to form $E G$ lines is significantly reduced as they enter the genital ridge and the gonad develops and organises. In males EG colonies are easily formed at E11.5, considerably more rarely formed at E12.5 and are no longer formed by E13.5. In common with teratoma formation from PTEN null germ cells, EG formation from gonadal germ cells involves the loss of the germ line specific marker Mvh (Kimura et al., 2003; Durcova-Hills et al., 2006) which is normally expressed from E11.5 and is required for survival of male germ cells at E11.5-E12.5 (Tanaka et al., 2000).

Formation of EG lines from male germ cells requires transient exposure to FGF2 in conjunction with SCF and LIF. After 24 hours of exposure to FGF2 the EG cells can remain pluripotent on feeder cells in the presence of LIF. Therefore a short pulse of FGF2 in combination with the other growth factors is sufficient to induce germ cell de-differentiation (Donovan and de Miguel, 2003; Durcova-Hills et al., 2006). This response can also be induced by other FGFs, particularly, FGF5, FGF9 and FGF10, however the action of FGF2 is apparently more potent in this context (DurcovaHills et al., 2006). FGFs function by binding to transmembrane tyrosine kinase receptors of the FGF receptor family. These ligand/receptor combinations are relatively promiscuous, with each FGF binding and activating several different receptors depending on the developmental context. However, DurcovaHills and colleagues found that expression of FGF receptors in gonadal germ cells is restricted, with only FGFR3 (and not FGFR1, FGFR2 or FGFR4) showing high levels of protein expression in E11.5 and E12.5 male (and female) germ cells. On this basis it has been proposed that the action of FGFs (particularly FGF2) is mediated through FGFR3 (Durcova-Hills et al., 2006) (Fig. 5). This has yet to be confirmed through further functional experiments.

Of interest in this context is the role of FGF9 in male somatic sex determination and germ cell survival (Colvin et al., 2001; Schmahl et al., 2004; DiNapoli et al., 2006). FGF9 null mice exhibit male to female sex reversal due to a failure of male somatic cell differentiation and loss of the developing germ cells through apoptosis (DiNapoli et al., 2006). Similarly the disruption of FGFR2 leads to aberrant male sex determination (Kim et al., 2007), indicating that FGF9 signalling through FGFR2 promotes male somatic cell development. In addition, the somatic sex reversal phenotype was lost when FGF9 null gonads were cultured in foetal calf serum, suggesting that small amounts of FGF activity in the serum could rescue the somatic cell phenotype. Despite this, the germ cells were still lost in this culture system indicating that FGF9 is required for both somatic sex determination and germ cell survival (DiNapoli et al., 2006). Therefore FGF9 is a candidate for directing the early stages of male germ lineage development and maintaining the integrity of male germ cells in this crucial early stage of development. Since germ cells do not normally transform in vivo, the function of FGF9 in normal male germ cell development could be expected to be restricted to their differentiation and survival. However, since FGF9 can induce EG formation in vitro, it is interesting to speculate that aberrant FGF9 function could contribute to germ cell transformation in vivo.

A striking feature of cell signalling mechanisms is that common downstream components and pathways are often utilised to mediate different ligand - receptor responses (Donovan and de Miguel, 2003). This is the case for the SCF/cKIT, FGF/FGFR and
LIF/gp130 ligand receptor complexes. For example signalling mediated by FGF and SCF involves transduction that is controlled by interactions modulated by AKT (Protein Kinase B) and PTEN. Loss of PTEN function leads to significantly increased teratoma formation and enhanced EG cell formation and therefore swings the developmental balance toward pluripotency at the expense of differentiation. Similarly, hyperactivation of AKT enhances the formation of EG cells (Kimura et al., 2008). It appears likely that these common effectors activate/repress an intricate network of down-stream pathways (eg miRNA expression, RNA regulation, cell cycle regulators) to greater and lesser extent and alter the balance of the message delivered to the developing germ cell (Fig. 5). This effect is likely to be more profoundly disrupted if a common effector of different signalling pathways is functionally deficient (for example PTEN) than if function of a single signalling molecule or receptor is lost. Clearly, for germ cells a choice between further differentiation or proliferation may play a key role in the potential for their progress along the normal developmental pathway or teratoma / pluripotent cell formation respectively.

\section{Conclusion}

Further understanding of normal germ cell development promises to inform our understanding of the processes through which germ cells are reprogrammed to form pluripotent cells (teratomas, EG cells). This process clearly involves the maintenance or reactivation of the key regulators of pluripotency, but whether these factors are actively involved is yet to be determined. However given the potential for these factors, together with regulators of proliferation and apoptosis to reprogram differentiated somatic cells, a role for the key regulators of pluripotency in germ cell reprogramming appears possible. If this is the case it is clear that other factors that control differentiation, survival and proliferation must also be involved as PGCs normally express pluripotency markers but do not normally transform. These factors may include members of the FGF, BMP, IL and KIT signalling pathways and their down-stream effectors. It is also clear that interaction of epigenetic modifiers and epigenetic patterns favouring the establishment of genomic totipotency play important roles in controlling the input and output of the genetic pathways crucial in mediating the balance between a cell that can deliver genomic totipotency while at the same time retain its germ cell identity.

\section{Acknowledgements}

I would like to thank Professor Azim Surani, Professor Andrew Sinclair, Professor Peter Koopman and Dr Craig Smith for valuable discussion and critical review of this manuscript. Patrick Western is supported through the Australian Research Council Centre of Excellence in Biotechnology and Development. In addition I would like to thank Jocelyn van den Bergen, Denise Miles and Andrew Sinclair for kindly allowing me to refer to unpublished data.

\section{References}

ADAMS, I.R. and MCLAREN, A. (2002). Sexually dimorphic development of mouse primordial germ cells: Switching from oogenesis to spermatogenesis. Development 129: 1155-1164.

ALMSTRUP, K., OTTESEN, A.M., SONNE, S.B., HOEI-HANSEN, C.E., LEFFERS, H., RAJPERT-DE MEYTS, E. and SKAKKEBAEK, N.E. (2005). Genomic and 
gene expression signature of the pre-invasive testicular carcinoma in situ. Cell Tissue Res 322: 159-165.

ANCELIN, K., LANGE, U.C., HAJKOVA, P., SCHNEIDER, R., BANNISTER, A.J., KOUZARIDES, T. and SURANI, M.A. (2006). Blimp1 associates with prmt5 and directs histone arginine methylation in mouse germ cells. Nat Cell Biol 8: 623630.

AVILION, A.A., NICOLIS, S.K., PEVNY, L.H., PEREZ, L., VIVIAN, N. and LOVELLBADGE, R. (2003). Multipotent cell lineages in early mouse development depend on sox2 function. Genes Dev 17: 126-140.

BALTUS, A.E., MENKE, D.B., HU, Y.C., GOODHEART, M.L., CARPENTER, A.E., DE ROOIJ, D.G. and PAGE, D.C. (2006). In germ cells of mouse embryonic ovaries, the decision to enter meiosis precedes premeiotic DNA replication. Nat Genet 38: 1430-1434.

BARTKOVA, J., LUKAS, C., SORENSEN, C.S., MEYTS, E.R., SKAKKEBAEK, N.E., LUKAS, J. and BARTEK, J. (2003). Deregulation of the rb pathway in human testicular germ cell tumours. J. Pathol 200: 149-156.

BENDSEN, E., BYSKOV, A.G., ANDERSEN, C.Y. and WESTERGAARD, L.G. (2006). Number of germ cells and somatic cells in human fetal ovaries during the first weeks after sex differentiation. Hum Reprod 21: 30-35.

BENDSEN, E., BYSKOV, A.G., LAURSEN, S.B., LARSEN, H.P., ANDERSEN, C.Y. and WESTERGAARD, L.G. (2003). Number of germ cells and somatic cells in human fetal testes during the first weeks after sex differentiation. Hum Reprod 18: 13-18.

BEST, D., SAHLENDER, D.A., WALTHER, N., PEDEN, A.A. and ADAMS, I.R. (2008). Sdmg1 is a conserved transmembrane protein associated with germ cell sex determination and germline-soma interactions in mic. Development 135: 1415-1425.

BEUMER, T.L., KIYOKAWA, H., ROEPERS-GAJADIEN, H.L., VAN DEN BOS, L.A., LOCK, T.M., GADEMAN, I.S., RUTGERS, D.H., KOFF, A. and DE ROOIJ, D.G. (1999). Regulatory role of p27kip1 in the mouse and human testis. Endocrinology 140: 1834-1840.

BEUMER, T.L., ROEPERS-GAJADIEN, H.L., GADEMAN, I.S., KAL, H.B. and DE ROOIJ, D.G. (2000). Involvement of the d-type cyclins in germ cell proliferation and differentiation in the mouse. Biol Reprod 63: 1893-1898.

BORTVIN, A., GOODHEART, M., LIAO, M. and PAGE, D.C. (2004). Dppa3 / pgc7 / stella is a maternal factor and is not required for germ cell specification in mice. BMC Dev Biol 4: 2.

BOURC'HIS, D. and BESTOR, T.H. (2004). Meiotic catastrophe and retrotransposon reactivation in male germ cells lacking dnmt3I. Nature 431: 96-99.

BOURC'HIS, D., XU, G.L., LIN, C.S., BOLLMAN, B. and BESTOR, T.H. (2001). Dnmt3l and the establishment of maternal genomic imprints. Science 294: 2536-2539.

BOWLES, J., KNIGHT, D., SMITH, C., WILHELM, D., RICHMAN, J., MAMIYA, S., YASHIRO, K., CHAWENGSAKSOPHAK, K., WILSON, M.J., ROSSANT, J. et al. (2006). Retinoid signaling determines germ cell fate in mice. Science 312 : 596-600.

BRENNAN, J. and CAPEL, B. (2004). One tissue, two fates: Molecular genetic events that underlie testis versus ovary development. Nat Rev Genet 5: 509521.

BROOK, F.A. and GARDNER, R.L. (1997). The origin and efficient derivation of embryonic stem cells in the mouse. Proc Natl Acad Sci U S A 94: 5709-5712.

BUEHR, M. and SMITH, A. (2003). Genesis of embryonic stem cells. Philos Trans $R$ Soc Lond B Biol Sci 358: 1397-402.

BYSKOV, A.G. (1986). Differentiation of mammalian embryonic gonad. Physiol Rev 66: 71-117.

CHAMBERS, I., COLBY, D., ROBERTSON, M., NICHOLS, J., LEE, S., TWEEDIE, S. and SMITH, A. (2003). Functional expression cloning of nanog, a pluripotency sustaining factor in embryonic stem cells. Cell 113: 643-655.

CHAMBERS, I., SILVA, J., COLBY, D., NICHOLS, J., NIJMEIJER, B., ROBERTSON, M., VRANA, J., JONES, K., GROTEWOLD, L. and SMITH, A. (2007) Nanog safeguards pluripotency and mediates germline development. Nature 450: 1230-1234.

CHENG, L., GEARING, D.P., WHITE, L.S., COMPTON, D.L., SCHOOLEY, K. and DONOVAN, P.J. (1994). Role of leukemia inhibitory factor and its receptor in mouse primordial germ cell growth. Development 120: 3145-3153.
COLVIN, J.S., GREEN, R.P., SCHMAHL, J., CAPEL, B. and ORNITZ, D.M. (2001). Male-to-female sex reversal in mice lacking fibroblast growth factor 9. Cell 104: 875-889.

COOKE, J.E., HEASMAN, J. and WYLIE, C.C. (1996). The role of interleukin-4 in the regulation of mouse primordial germ cell numbers. Dev Biol 174: 14-21.

COOLS, M., DROP, S.L., WOLFFENBUTTEL, K.P., OOSTERHUIS, J.W. and LOOIJENGA, L.H. (2006). Germ cell tumors in the intersex gonad: Old paths, new directions, moving frontiers. Endocr Rev 27: 468-484.

DE FELICI, M. and DOLCI, S. (1991). Leukemia inhibitory factor sustains the survival of mouse primordial germ cells cultured on tm4 feeder layers. Dev Biol 147: 281-284.

DE SOUSA LOPES, S.M., ROELEN, B.A., MONTEIRO, R.M., EMMENS, R., LIN, H.Y., LI, E., LAWSON, K.A. and MUMMERY, C.L. (2004). Bmp signaling mediated by alk2 in the visceral endoderm is necessary for the generation of primordial germ cells in the mouse embryo. Genes Dev 18: 1838-1849.

DINAPOLI, L., BATCHVAROV, J. and CAPEL, B. (2006). Fgf9 promotes survival of germ cells in the fetal testis. Development 133: 1519-1527.

DOLCI, S., PESCE, M. and DE FELICI, M. (1993). Combined action of stem cell factor, leukemia inhibitory factor, and camp on in vitro proliferation of mouse primordial germ cells. Mol Reprod Dev 35: 134-139.

DOLCI, S., WILLIAMS, D.E., ERNST, M.K., RESNICK, J.L., BRANNAN, C.I., LOCK, L.F., LYMAN, S.D., BOSWELL, H.S. and DONOVAN, P.J. (1991). Requirement for mast cell growth factor for primordial germ cell survival in culture. Nature 352: 809-811.

DONOVAN, P.J. and DE MIGUEL, M.P. (2003). Turning germ cells into stem cells. Curr Opin Genet Dev 13: 463-471.

DUDLEY, B.M., RUNYAN, C., TAKEUCHI, Y., SCHAIBLE, K. and MOLYNEAUX, K. (2007). Bmp signaling regulates pgc numbers and motility in organ culture. Mech Dev 124: 68-77.

DURCOVA-HILLS, G., ADAMS, I.R., BARTON, S.C., SURANI, M.A. and MCLAREN, A. (2006). The role of exogenous fibroblast growth factor-2 on the reprogramming of primordial germ cells into pluripotent stem cells. Stem Cells 24: 14411449.

DURCOVA-HILLS, G., AINSCOUGH, J. and MCLAREN, A. (2001). Pluripotential stem cells derived from migrating primordial germ cells. Differentiation 68: 220226.

DURCOVA-HILLS, G., WIANNY, F., MERRIMAN, J., ZERNICKA-GOETZ, M. and MCLAREN, A. (2003). Developmental fate of embryonic germ cells (egcs), in vivo and in vitro. Differentiation 71: 135-141.

EGUIZABAL, C., BOYANO, M.D., DIEZ-TORRE, A., ANDRADE, R., ANDOLLO, N., DE FELICI, M. and ARECHAGA, J. (2007). Interleukin-2 induces the proliferation of mouse primordial germ cells in vitro. Int $J$ Dev Biol 51: 731-738.

ERHARDT, S., SU, I.H., SCHNEIDER, R., BARTON, S., BANNISTER, A.J., PEREZ-BURGOS, L., JENUWEIN, T., KOUZARIDES, T., TARAKHOVSKY, A. and SURANI, M.A. (2003). Consequences of the depletion of zygotic and embryonic enhancer of zeste 2 during preimplantation mouse development. Development 130: 4235-4248.

GARDNER, R.L. and ROSSANT, J. (1979). Investigation of the fate of 4-5 day postcoitum mouse inner cell mass cells by blastocyst injection. J Embryol Exp Morphol 52: 141-152.

GASKELL, T.L., ESNAL, A., ROBINSON, L.L., ANDERSON, R.A. and SAUNDERS, P.T. (2004). Immunohistochemical profiling of germ cells within the human fetal testis: Identification of three subpopulations. Biol Reprod 71: 2012-2021.

GINSBURG, M., SNOW, M.H. and MCLAREN, A. (1990). Primordial germ cells in the mouse embryo during gastrulation. Development 110: 521-528.

GODDARD, N.C., MCINTYRE, A., SUMMERSGILL, B., GILBERT, D., KITAZAWA, S. and SHIPLEY, J. (2007). Kit and ras signalling pathways in testicular germ cell tumours: New data and a review of the literature. Int $J$ Androl 30: 337-48.

GODIN, I. and WYLIE, C.C. (1991). Tgf beta 1 inhibits proliferation and has a chemotropic effect on mouse primordial germ cells in culture. Development 113: 1451-1457.

GUAN, K., NAYERNIA, K., MAIER, L.S., WAGNER, S., DRESSEL, R., LEE, J.H., NOLTE, J., WOLF, F., LI, M., ENGEL, W. et al. (2006). Pluripotency of spermatogonial stem cells from adult mouse testis. Nature 440: 1199-1203.

GUBBAY, J., COLLIGNON, J., KOOPMAN, P., CAPEL, B., ECONOMOU, A., MUNSTERBERG, A., VIVIAN, N., GOODFELLOW, P. and LOVELL-BADGE, R. 
(1990). A gene mapping to the sex-determining region of the mouse y chromosome is a member of a novel family of embryonically expressed genes. Nature 346: $245-50$.

HAJKOVA, P., ERHARDT, S., LANE, N., HAAF, T., EL-MAARRI, O., REIK, W., WALTER, J. and SURANI, M.A. (2002). Epigenetic reprogramming in mouse primordial germ cells. Mech Dev 117: 15-23.

HART, A.H., HARTLEY, L., PARKER, K., IBRAHIM, M., LOOIJENGA, L.H., PAUCHNIK, M., CHOW, C.W. and ROBB, L. (2005). The pluripotency homeobox gene nanog is expressed in human germ cell tumors. Cancer 104: 2092-8.

HARVEY, M., MCARTHUR, M.J., MONTGOMERY, C.A., JR., BRADLEY, A. and DONEHOWER, L.A. (1993). Genetic background alters the spectrum of tumors that develop in p53-deficient mice. FASEB J 7: 938-943.

HATA, K., OKANO, M., LEI, H. and LI, E. (2002). Dnmt3I cooperates with the dnmt3 family of de novo DNA methyltransferases to establish maternal imprints in mice. Development 129: 1983-1993.

HILSCHER, B., HILSCHER, W., BULTHOFF-OHNOLZ, B., KRAMER, U., BIRKE, A., PELZER, H. and GAUSS, G. (1974). Kinetics of gametogenesis. I. Comparative histological and autoradiographic studies of oocytes and transitional prospermatogonia during oogenesis and prespermatogenesis. Cell Tissue Res 154: 443-470.

HOEI-HANSEN, C.E., ALMSTRUP, K., NIELSEN, J.E., BRASK SONNE, S., GRAEM, N., SKAKKEBAEK, N.E., LEFFERS, H. and RAJPERT-DE MEYTS, E. (2005) Stem cell pluripotency factor NANOG is expressed in human fetal gonocytes, testicular carcinoma in situ and germ cell tumours. Histopathology 47: 48-56.

HOGARTH, C., ITMAN, C., JANS, D.A. and LOVELAND, K.L. (2005). Regulated nucleocytoplasmic transport in spermatogenesis: A driver of cellular differentiation? Bioessays 27: 1011-1025.

HOGARTH, C.A., JANS, D.A. and LOVELAND, K.L. (2007). Subcellular distribution of importins correlates with germ cell maturation. Dev Dyn 236: 2311-2320.

ITMAN, C., MENDIS, S., BARAKAT, B. and LOVELAND, K.L. (2006). All in the family: Tgf-beta family action in testis development. Reproduction 132: 233246.

KANATSU-SHINOHARA, M., INOUE, K., LEE, J., YOSHIMOTO, M., OGONUKI, N., MIKI, H., BABA, S., KATO, T., KAZUKI, Y., TOYOKUNI, S. et al. (2004). Generation of pluripotent stem cells from neonatal mouse testis. Cell119: 1001 1012

KANEDA, M., OKANO, M., HATA, K., SADO, T., TSUJIMOTO, N., LI, E. and SASAKI, H. (2004). Essential role for de novo DNA methyltransferase dnmt3a in paternal and maternal imprinting. Nature 429: 900-903.

KATO, Y., KANEDA, M., HATA, K., KUMAKI, K., HISANO, M., KOHARA, Y., OKANO, M., LI, E., NOZAKI, M. and SASAKI, H. (2007). Role of the dnmt3 family in de novo methylation of imprinted and repetitive sequences during male germ cell development in the mouse. Hum Mol Genet 16: 2272-2280.

KEDDE, M., STRASSER, M.J., BOLDAJIPOUR, B., VRIELINK, J.A., SLANCHEV, K., LE SAGE, C., NAGEL, R., VOORHOEVE, P.M., VAN DUIJSE, J., ØROM, U.A. et al. (2007). Rna-binding protein dnd1 inhibits microrna access to target mrna. Cell 131: 1273-1286.

KEHLER, J., TOLKUNOVA, E., KOSCHORZ, B., PESCE, M., GENTILE, L., BOIANI, M., LOMELI, H., NAGY, A., MCLAUGHLIN, K.J., SCHOLER, H.R. et al. (2004). Oct4 is required for primordial germ cell survival. EMBO Rep 5: 1078 1083.

KIM, Y., BINGHAM, N., SEKIDO, R., PARKER, K.L., LOVELL-BADGE, R. and CAPEL, B. (2007). Fibroblast growth factor receptor 2 regulates proliferation and sertoli differentiation during male sex determination. Proc Natl Acad Sci U $S$ A 104: 16558-16563.

KIMURA, T., SUZUKI, A., FUJITA, Y., YOMOGIDA, K., LOMELI, H., ASADA, N., IKEUCHI, M., NAGY, A., MAK, T.W. and NAKANO, T. (2003). Conditional loss of pten leads to testicular teratoma and enhances embryonic germ cell production. Development 130: 1691-1700.

KIMURA, T., TOMOOKA, M., YAMANO, N., MURAYAMA, K., MATOBA, S., UMEHARA, H., KANAI, Y. and NAKANO, T. (2008). Akt signaling promotes derivation of embryonic germ cells from primordial germ cells. Development 135: 869-879.

KOOPMAN, P., GUBBAY, J., VIVIAN, N., GOODFELLOW, P. and LOVELLBADGE, R. (1991). Male development of chromosomally female mice transgenic for sry. Nature 351: 117-121.
KOSHIMIZU, U., TAGA, T., WATANABE, M., SAITO, M., SHIRAYOSHI, Y., KISHIMOTO, T. and NAKATSUJI, N. (1996). Functional requirement of gp130mediated signaling for growth and survival of mouse primordial germ cells in vitro and derivation of embryonic germ (eg) cells. Development 122: 1235-1242.

KOUBOVA, J., MENKE, D.B., ZHOU, Q., CAPEL, B., GRISWOLD, M.D. and PAGE D.C. (2006). Retinoic acid regulates sex-specific timing of meiotic initiation in mice. Proc Natl Acad Sci 103: 2474-2479.

LA SALLE, S., MERTINEIT, C., TAKETO, T., MOENS, P.B., BESTOR, T.H. and TRASLER, J.M. (2004). Windows for sex-specific methylation marked by DNA methyltransferase expression profiles in mouse germ cells. Dev Biol 268: 403415.

LABOSKY, P.A., BARLOW, D.P. and HOGAN, B.L. (1994). Mouse embryonic germ (eg) cell lines: Transmission through the germline and differences in the methylation imprint of insulin-like growth factor 2 receptor (igf2r) gene compared with embryonic stem (es) cell lines. Development 120: 3197-3204.

LANE, N., DEAN, W., ERHARDT, S., HAJKOVA, P., SURANI, A., WALTER, J. and REIK, W. (2003). Resistance of iaps to methylation reprogramming may provide a mechanism for epigenetic inheritance in the mouse. Genesis 35: 88-93.

LANGE, U.C., SAITOU, M., WESTERN, P.S., BARTON, S.C. and SURANI, M.A. (2003). The fragilis interferon-inducible gene family of transmembrane proteins is associated with germ cell specification in mice. BMC Dev Biol 3: 1.

LAWSON, K.A., DUNN, N.R., ROELEN, B.A., ZEINSTRA, L.M., DAVIS, A.M., WRIGHT, C.V., KORVING, J.P. and HOGAN, B.L. (1999). Bmp4 is required for the generation of primordial germ cells in the mouse embryo. Genes Dev 13: 424-436.

LAWSON, K.A. and HAGE, W.J. (1994). Clonal analysis of the origin of primordial germ cells in the mouse. Ciba Found Symp 182: 68-84.

LE SAGE, C., NAGEL, R., EGAN, D.A., SCHRIER, M., MESMAN, E., MANGIOLA A., ANILE, C., MAIRA, G., MERCATELLI, N., CIAFRE, S.A. et al. (2007) Regulation of the p27(kip1) tumor suppressor by mir-221 and mir-222 promotes cancer cell proliferation. EMBO J 26: 3699-3708.

LOOIJENGA, L.H., STOOP, H., DE LEEUW, H.P., DE GOUVEIA BRAZAO, C.A., GILLIS, A.J., VAN ROOZENDAAL, K.E., VAN ZOELEN, E.J., WEBER, R.F. WOLFFENBUTTEL, K.P., VAN DEKKEN, H., HONECKER, F., BOKEMEYER, C., PERLMAN, E.J., SCHNEIDER, D.T., KONONEN, J., SAUTER, G. and OOSTERHUIS, J.W. (2003) POU5F1 (OCT3/4) identifies cells with pluripotent potential in human germ cell tumors. Cancer Research 63: 2244-2250.

LUCIFERO, D., LA SALLE, S., BOURC'HIS, D., MARTEL, J., BESTOR, T.H. and TRASLER, J.M. (2007). Coordinate regulation of DNA methyltransferase expression during oogenesis. BMC Dev Biol 7: 36 .

MALDONADO-SALDIVIA, J., VANDEN BERGEN, J., KROUSKOS, M., GILCHRIST, M., LEE, C., LI, R., SINCLAIR, A.H., SURANI, M.A. and WESTERN, P.S. (2007). Dppa2 and dppa4 are closely linked sap motif genes restricted to pluripotent cells and the germ line. Stem Cells 25: 19-28.

MATIN, A. (2007). What leads from dead-end? Cell mol life Sci 64: 1317-22.

MATSUI, Y., TOKSOZ, D., NISHIKAWA, S., NISHIKAWA, S., WILLIAMS, D. ZSEBO, K. and HOGAN, B.L. (1991). Effect of steel factor and leukaemia inhibitory factor on murine primordial germ cells in culture. Nature 353: 750-752.

MATSUI, Y., ZSEBO, K. and HOGAN, B.L. (1992). Derivation of pluripotential embryonic stem cells from murine primordial germ cells in culture. Cell 70: 841 847.

MCINTYRE, A., SUMMERSGILL, B., GRYGALEWICZ, B., GILLIS, A.J., STOOP, J., VAN GURP, R.J., DENNIS, N., FISHER, C., HUDDART, R., COOPER, C. et al. (2005). Amplification and overexpression of the kit gene is associated with progression in the seminoma subtype of testicular germ cell tumors of adolescents and adults. Cancer Res 65: 8085-8089.

MCLAREN, A. (1984). Meiosis and differentiation of mouse germ cells. Symp Soc Exp Biol 38: 7-23.

MCLAREN, A. (2003). Primordial germ cells in the mouse. Dev Biol 262: 1-15.

MCLAREN, A. and SOUTHEE, D. (1997). Entry of mouse embryonic germ cells into meiosis. Dev Biol 187: 107-113.

MESNARD, D., GUZMAN-AYALA, M. and CONSTAM, D.B. (2006). Nodal specifies embryonic visceral endoderm and sustains pluripotent cells in the epiblast before overt axial patterning. Development 133: 2497-2505.

MITSUI, K., TOKUZAWA, Y., ITOH, H., SEGAWA, K., MURAKAMI, M., TAKAHASHI, K., MARUYAMA, M., MAEDA, M. and YAMANAKA, S. (2003). The homeoprotein 
nanog is required for maintenance of pluripotency in mouse epiblast and es cells. Cell 113: 631-642.

NAKAMURA, T., ARAI, Y., UMEHARA, H., MASUHARA, M., KIMURA, T., TANIGUCHI, H., SEKIMOTO, T., IKAWA, M., YONEDA, Y., OKABE, M. et al. (2007). Pgc7/stella protects against DNA demethylation in early embryogenesis. Nat Cell Biol 9: 64-71.

NICHOLS, J., ZEVNIK, B., ANASTASSIADIS, K., NIWA, H., KLEWE-NEBENIUS, D., CHAMBERS, I., SCHOLER, H. and SMITH, A. (1998). Formation of pluripotent stem cells in the mammalian embryo depends on the pou transcription factor oct4. Cell 95: 379-391.

NIWA, H., MIYAZAKI, J. and SMITH, A.G. (2000). Quantitative expression of oct$3 / 4$ defines differentiation, dedifferentiation or self-renewal of es cells. Nat Genet 24: 372-376.

NOGUCHI, T. and STEVENS, L.C. (1982). Primordial germ cell proliferation in fetal testes in mouse strains with high and low incidences of congenital testicular teratomas. J Natl Cancer Inst 69: 907-913.

O'CARROLL, D., ERHARDT, S., PAGANI, M., BARTON, S.C., SURANI, M.A. and JENUWEIN, T. (2001). The polycomb-group gene ezh2 is required for early mouse development. Mol Cell Biol 21: 4330-4336.

OHINATA, Y., PAYER, B., O'CARROLL, D., ANCELIN, K., ONO, Y., SANO, M., BARTON, S.C., OBUKHANYCH, T., NUSSENZWEIG, M., TARAKHOVSKY, A. et al. (2005). Blimp1 is a critical determinant of the germ cell lineage in mice. Nature 436: 207-213.

OKITA, K., ICHISAKA, T. and YAMANAKA, S. (2007). Generation of germlinecompetent induced pluripotent stem cells. Nature 448: 313-317.

OOSTERHUIS, J.W. and LOOIJENGA, L.H. (2005). Testicular germ-cell tumours in a broader perspective. Nat Rev Cancer 5: 210-222.

OOSTERHUIS, J.W., STOOP, H., HONECKER, F. and LOOIJENGA, L.H. (2007). Why human extragonadal germ cell tumours occur in the midline of the body: Old concepts, new perspectives. Int $J$ Androl 30: 256-63.

PAYER, B., CHUVA DE SOUSA LOPES, S.M., BARTON, S.C., LEE, C., SAITOU, M. and SURANI, M.A. (2006). Generation of stella-gfp transgenic mice: A novel tool to study germ cell development. Genesis 44: 75-83.

PAYER, B., SAITOU, M., BARTON, S.C., THRESHER, R., DIXON, J.P., ZAHN, D., COLLEDGE, W.H., CARLTON, M.B., NAKANO, T. and SURANI, M.A. (2003). Stella is a maternal effect gene required for normal early development in mice. Curr Biol 13: 2110-2117.

PESCE, M., FARRACE, M.G., PIACENTINI, M., DOLCI, S. and DE FELICI, M. (1993). Stem cell factor and leukemia inhibitory factor promote primordial germ cell survival by suppressing programmed cell death (apoptosis). Development 118: 1089-1094.

RAJPERT-DE MEYTS, E., BARTKOVA, J., SAMSON, M., HOEI-HANSEN, C.E., FRYDELUND-LARSEN, L., BARTEK, J. and SKAKKEBAEK, N.E. (2003). The emerging phenotype of the testicular carcinoma in situ germ cell. APMIS 111: 267-78.

RAJPERT-DE MEYTS, E., HANSTEIN, R., JORGENSEN, N., GRAEM, N., VOGT, P.H. and SKAKKEBAEK, N.E. (2004). Developmental expression of pou5f1 (oct-3/4) in normal and dysgenetic human gonads. Hum Reprod 19: 1338-1344.

REGENASS, U., FRIEDRICH, T.D. and STEVENS, L.C. (1982). Experimental induction of testicular teratomas in dissociated-reaggregated chimaeric gonads. J Embryol Exp Morphol 72: 153-167.

RESNICK, J.L., BIXLER, L.S., CHENG, L. and DONOVAN, P.J. (1992). Long-term proliferation of mouse primordial germ cells in culture. Nature 359: 550-551.

REUTER, V.E. (2005). Origins and molecular biology of testicular germ cell tumors. Mod Pathol 18: S51-S60.

RICHARDS, A.J., ENDERS, G.C. and RESNICK, J.L. (1999). Activin and tgfbeta limit murine primordial germ cell proliferation. Dev Biol 207: 470-475.

RIVERS, E.N. and HAMILTON, D.W. (1986). Morphologic analysis of spontaneous teratocarcinogenesis in developing testes of strain 129/sv-ter mice. Am J Pathol 124: 263-280.

ROSS, A., MUNGER, S. and CAPEL, B. (2007). Bmp7 regulates germ cell proliferation in mouse fetal gonads. Sex Dev 1: 127-137.

RUNYAN, C., SCHAIBLE, K., MOLYNEAUX, K., WANG, Z., LEVIN, L. and WYLIE, C. (2006). Steel factor controls midline cell death of primordial germ cells and is essential for their normal proliferation and migration. Development 133: 48614869.
SAITOU, M., BARTON, S.C. and SURANI, M.A. (2002). A molecular programme for the specification of germ cell fate in mice. Nature 418: 293-300.

SAKAI, Y., SUETAKE, I., SHINOZAKI, F., YAMASHINA, S. and TAJIMA, S. (2004). Co-expression of de novo DNA methyltransferases dnmt3a2 and dnmt3l in gonocytes of mouse embryos. Gene Expr Patterns 5: 231-237.

SAKUMA, Y., SAKURAI, S., OGUNI, S., HIRONAKA, M. and SAITO, K. (2003). Alterations of the c-kit gene in testicular germ cell tumors. Cancer Science 94: 486-491.

SAPSFORD, C.S. (1962). Changes of the cells of the sex cords and seminiferous tubules during the development of the testis of the rat and mouse. Aust $\mathrm{J} Z$ Zool 10: 178-194.

SATO, M., KIMURA, T., KUROKAWA, K., FUJITA, Y., ABE, K., MASUHARA, M., YASUNAGA, T., RYO, A., YAMAMOTO, M. and NAKANO, T. (2002). Identification of pgc7, a new gene expressed specifically in preimplantation embryos and germ cells. Mech Dev 113: 91-94.

SATO, S., YOSHIMIZU, T., SATO, E. and MATSUI, Y. (2003). Erasure of methylation imprinting of igf $2 \mathrm{r}$ during mouse primordial germ-cell development. $\mathrm{Mol}$ Reprod Dev 65: 41-50.

SCHMAHL, J., KIM, Y., COLVIN, J.S., ORNITZ, D.M. and CAPEL, B. (2004). Fgf9 induces proliferation and nuclear localization of fgfr2 in sertoli precursors during male sex determination. Development 131: 3627-3636.

SCHOLER, H.R., DRESSLER, G.R., BALLING, R., ROHDEWOHLD, H. and GRUSS, P. (1990). Oct-4: A germline-specific transcription factor mapping to the mouse t-complex. EMBO J 9: 2185-2195.

SEKI, Y., HAYASHI, K., ITOH, K., MIZUGAKI, M., SAITOU, M. and MATSUI, Y. (2005). Extensive and orderly reprogramming of genome-wide chromatin modifications associated with specification and early development of germ cells in mice. Dev Biol 278: 440-458.

SEKI, Y., YAMAJI, M., YABUTA, Y., SANO, M., SHIGETA, M., MATSUI, Y., SAGA, Y., TACHIBANA, M., SHINKAI, Y. and SAITOU, M. (2007). Cellular dynamics associated with the genome-wide epigenetic reprogramming in migrating primordial germ cells in mice. Development 134: 2627-2638.

SEYDOUX, G. and BRAUN, R.E. (2006). Pathway to totipotency: Lessons from germ cells. Cell 127: 891-904

SHAMBLOTT, M.J., AXELMAN, J., WANG, S., BUGG, E.M., LITTLEFIELD, J.W., DONOVAN, P.J., BLUMENTHAL, P.D., HUGGINS, G.R. and GEARHART, J.D. (1998). Derivation of pluripotent stem cells from cultured human primordial germ cells. Proc Natl Acad Sci U S A 95: 13726-31.

SHOVLIN, T.C., BOURC'HIS, D., LA SALLE, S., O'DOHERTY, A., TRASLER, J.M., BESTOR, T.H. and WALSH, C.P. (2007). Sex-specific promoters regulate dnmt3l expression in mouse germ cells. Hum Reprod 22: 457-467.

SILVA, J., MAK, W., ZVETKOVA, I., APPANAH, R., NESTEROVA, T.B., WEBSTER, Z., PETERS, A.H., JENUWEIN, T., OTTE, A.P. and BROCKDORFF, N. (2003). Establishment of histone $h 3$ methylation on the inactive $x$ chromosome requires transient recruitment of eed-enx1 polycomb group complexes. Developmental Cell 4: 481-495.

SINCLAIR, A.H., BERTA, P., PALMER, M.S., HAWKINS, J.R., GRIFFITHS, B.L., SMITH, M.J., FOSTER, J.W., FRISCHAUF, A.M., LOVELL-BADGE, R. and GOODFELLOW, P.N. (1990). A gene from the human sex-determining region encodes a protein with homology to a conserved DNA-binding motif. Nature 346: 240-244.

SKAKKEBAEK, N.E., RAJPERT-DE MEYTS, E. and MAIN, K.M. (2001). Testicular dysgenesis syndrome: An increasingly common developmental disorder with environmental aspects. Hum Reprod 16: 972-978.

SNOW, M.H. (1981). Autonomous development of parts isolated from primitivestreak-stage mouse embryos. Is development clonal? J Embryol Exp Morphol 65: 269-287.

STALLOCK, J., MOLYNEAUX, K., SCHAIBLE, K., KNUDSON, C.M. and WYLIE, C. (2003). The pro-apoptotic gene bax is required for the death of ectopic primordial germ cells during their migration in the mouse embryo. Development 130: 6589-6597.

STEBLER, J., SPIELER, D., SLANCHEV, K., MOLYNEAUX, K.A., RICHTER, U., COJOCARU, V., TARABYKIN, V., WYLIE, C., KESSEL, M. and RAZ, E. (2004). Primordial germ cell migration in the chick and mouse embryo: The role of the chemokine sdf-1/cxcl12. Dev Biol 272: 351-361.

STEVENS, L.C. (1964). Experimental production of testicular teratomas in mice. Proc Natl Acad Sci U S A 52: 654-661. 
STEVENS, L.C. (1966). Development of resistance to teratocarcinogenesis by primordial germ cells in mice. J Natl Cancer Inst 37: 859-867.

STEVENS, L.C. (1967). Origin of testicular teratomas from primordial germ cells in mice. J Natl Cancer Inst 38: 549-552.

STEVENS, L.C. (1973). A new inbred subline of mice (129-tersv) with a high incidence of spontaneous congenital testicular teratomas. J Nat/ Cancer Inst 50: 235-242.

STEVENS, L.C. (1984). Spontaneous and experimentally induced testicular teratomas in mice. Cell Differ 15: 69-74.

STEWART, C.L., GADI, I. and BHATT, H. (1994). Stem cells from primordial germ cells can reenter the germ line. Dev Biol 161: 626-628.

STROME, S. and LEHMANN, R. (2007). Germ versus soma decisions: Lessons from flies and worms. Science 316: 392-393.

SUGIMOTO, M. and ABE, K. (2007). X chromosome reactivation initiates in nascent primordial germ cells in mice. PLoS Genetics 3: e116.

SURANI, M.A., HAYASHI, K. and HAJKOVA, P. (2007). Genetic and epigenetic regulators of pluripotency. Cell 128: 747-762.

SUZUKI, A. and SAGA, Y. (2008). Nanos2 suppresses meiosis and promotes male germ cell differentiation. Genes Dev 22: 430-435.

SUZUKI, A., TSUDA, M. and SAGA, Y. (2007). Functional redundancy among nanos proteins and a distinct role of nanos 2 during male germ cell development. Development 134: 77-83.

SUZUKI, H., TSUDA, M., KISO, M. and SAGA, Y. (2008). Nanos3 maintains the germ cell lineage in the mouse by suppressing both bax-dependent and independent apoptotic pathways. Dev Biol 318: 133-142.

SVINGEN, T., BEVERDAM, A., BERNARD, P., MCCLIVE, P., HARLEY, V.R., SINCLAIR, A.H. and KOOPMAN, P. (2007). Sex-specific expression of a novel gene tmem184a during mouse testis differentiation. Reproduction 133: 983 989.

TACHIBANA, M., UEDA, J., FUKUDA, M., TAKEDA, N., OHTA, T., IWANARI, H., SAKIHAMA, T., KODAMA, T., HAMAKUBO, T. and SHINKAI, Y. (2005). Histone methyltransferases g9a and glp form heteromeric complexes and are both crucial for methylation of euchromatin at h3-k9. Genes Dev 19: 815-826.

TADA, M., TADA, T., LEFEBVRE, L., BARTON, S.C. and SURANI, M.A. (1997). Embryonic germ cells induce epigenetic reprogramming of somatic nucleus in hybrid cells. EMBO J 16: 6510-6520.

TADA, M., TAKAHAMA, Y., ABE, K., NAKATSUJI, N. and TADA, T. (2001). Nuclear reprogramming of somatic cells by in vitro hybridization with es cells. Curr Biol 11: 1553-1558.

TADA, T., TADA, M., HILTON, K., BARTON, S.C., SADO, T., TAKAGI, N. and SURANI, M.A. (1998). Epigenotype switching of imprintable loci in embryonic germ cells. Dev Genes Evol 207: 551-561.

TAKAHASHI, K., TANABE, K., OHNUKI, M., NARITA, M., ICHISAKA, T., TOMODA, K. and S., Y. (2007). Induction of pluripotent stem cells from adult human fibroblasts by defined factors. Cell 131: 861-872.

TAKAHASHI, K. and YAMANAKA, S. (2006). Induction of pluripotent stem cells from mouse embryonic and adult fibroblast cultures by defined factors. Cell126: 663-676.

TAKEUCHI, Y., MOLYNEAUX, K., RUNYAN, C., SCHAIBLE, K. and WYLIE, C. (2005). The roles of fgf signaling in germ cell migration in the mouse. Development 132: 5399-5409.

TAM, P.P. and SNOW, M.H. (1981). Proliferation and migration of primordial germ cells during compensatory growth in mouse embryos. J Embryol Exp Morphol 64: $133-147$

TAM, P.P. and ZHOU, S.X. (1996). The allocation of epiblast cells to ectodermal and germ-line lineages is influenced by the position of the cells in the gastrulating mouse embryo. Dev Biol 178: 124-132.

TAM, P.P., ZHOU, S.X. and TAN, S.S. (1994). X-chromosome activity of the mouse primordial germ cells revealed by the expression of an x-linked lacz transgene. Development 120: 2925-2932.

TANAKA, S.S. and MATSUI, Y. (2002). Developmentally regulated expression of mil-1 and mil-2, mouse interferon-induced transmembrane protein like genes, during formation and differentiation of primordial germ cells. Gene Expr Patterns 2: 297-303.

TANAKA, S.S., NAGAMATSU, G., TOKITAKE, Y., KASA, M., TAM, P.P. and
MATSUI, Y. (2004). Regulation of expression of mouse interferon-induced transmembrane protein like gene-3, ifitm3 (mil-1, fragilis), in germ cells. Dev Dyn 230: 651-659.

TANAKA, S.S., TOYOOKA, Y., AKASU, R., KATOH-FUKUI, Y., NAKAHARA, Y., SUZUKI, R., YOKOYAMA, M. and NOCE, T. (2000). The mouse homolog of drosophila vasa is required for the development of male germ cells. Genes Dev 14: 841-853

TANAKA, S.S., YAMAGUCHI, Y.L., TSOI, B., LICKERT, H. and TAM, P.P. (2005). Ifitm/mil/fragilis family proteins ifitm 1 and ifitm 3 play distinct roles in mouse primordial germ cell homing and repulsion. Dev Cell 9: 745-756.

TANAKA, T.S., KUNATH, T., KIMBER, W.L., JARADAT, S.A., STAGG, C.A., USUDA, M., YOKOTA, T., NIWA, H., ROSSANT, J. and KO, M.S. (2002). Gene expression profiling of embryo-derived stem cells reveals candidate genes associated with pluripotency and lineage specificity. Genome Res 12: 19211928.

TANAKA, T.S., LOPEZ DE SILANES, I., SHAROVA, L.V., AKUTSU, H., YOSHIKAWA, T., AMANO, H., YAMANAKA, S., GOROSPE, M. and KO, M.S (2006). Esg1, expressed exclusively in preimplantation embryos, germline, and embryonic stem cells, is a putative rna-binding protein with broad rna targets Dev Growth Differ 48: 381-390.

TRAUTMANN, E., GUERQUIN, M. J., DUQUENNE, C., LAHAYE, J.B., HABERT, R. and LIVERA, G. (2008). Retinoic acid prevents germ cell mitotic arrest in mouse fetal testes. Cell Cycle 7: 656-664

TSUDA, M., SASAOKA, Y., KISO, M., ABE, K., HARAGUCHI, S., KOBAYASHI, S. and SAGA, Y. (2003). Conserved role of nanos proteins in germ cell development. Science 301: 1239-1241.

VALLIER, L., REYNOLDS, D. and PEDERSEN, R.A. (2004). Nodal inhibits differentiation of human embryonic stem cells along the neuroectodermal default pathway. Dev Biol 275: 403-421.

VERGOUWEN, R.P., JACOBS, S.G., HUISKAMP, R., DAVIDS, J.A. and DE ROOIJ, D.G. (1991). Proliferative activity of gonocytes, sertoli cells and interstitial cells during testicular development in mice. J Reprod Fertil 93: 233-243.

VOORHOEVE, P.M., LE SAGE, C., SCHRIER, M., GILLIS, A.J., STOOP, H. NAGEL, R., LIU, Y.P., VAN DUIJSE, J., DROST, J., GRIEKSPOOR, A. et al. (2007). A genetic screen implicates mirna-372 and mirna-373 as oncogenes in testicular germ cell tumors. Adv Exp Med Biol 604: 17-46.

WEBSTER, K.E., O'BRYAN, M.K., FLETCHER, S., CREWTHER, P.E., AAPOLA, U., CRAIG, J., HARRISON, D.K., AUNG, H., PHUTIKANIT, N., LYLE, R. et al. (2005). Meiotic and epigenetic defects in dnmt3l-knockout mouse spermatogenesis. Proc Natl Acad Sci U S A 102: 4068-4073.

WERNIG, M., MEISSNER, A., FOREMAN, R., BRAMBRINK, T., KU, M., HOCHEDLINGER, K., BERNSTEIN, B.E. and JAENISCH, R. (2007). In vitro reprogramming of fibroblasts into a pluripotent es-cell-like state. Nature 448: 318-324.

WESTERN, P., MALDONADO-SALDIVIA, J., VAN DEN BERGEN, J., HAJKOVA P., SAITOU, M., BARTON, S. and SURANI, M.A. (2005). Analysis of esg1 expression in pluripotent cells and the germline reveals similarities with oct 4 and sox 2 and differences between human pluripotent cell lines. Stem Cells 23 . 1436-1442.

WESTERN, P.S., MILES, D.C., VAN DEN BERGEN, J.A., BURTON, M. and SINCLAIR, A.H. (2008). Dynamic regulation of mitotic arrest in fetal male germ cells. Stem Cells 26: 339-347.

WILHELM, D., HIRAMATSU, R., MIZUSAKI, H., WIDJAJA, L., COMBES, A.N., KANAI, Y. and KOOPMAN, P. (2007a). Sox9 regulates prostaglandin d synthase gene transcription in vivo to ensure testis development. J Biol Chem 282: 10553-10560

WILHELM, D. and KOOPMAN, P. (2006). The makings of maleness: Towards an integrated view of male sexual development. Nat Rev Genet 7: 620-631.

WILHELM, D., MARTINSON, F., BRADFORD, S., WILSON, M.J., COMBES, A.N BEVERDAM, A., BOWLES, J., MIZUSAKI, H. and KOOPMAN, P. (2005). Sertoli cell differentiation is induced both cell-autonomously and through prostaglandin signaling during mammalian sex determination. Dev Biol 287: 111-124.

WILHELM, D., PALMER, S. and KOOPMAN, P. (2007b). Sex determination and gonadal development in mammals. Physiol Rev 87: 1-28.

WYLIE, C. (1999). Germ cells. Cell 96: 165-174.

YABUTA, Y., KURIMOTO, K., OHINATA, Y., SEKI, Y. and SAITOU, M. (2006). Gene expression dynamics during germline specification in mice identified by 
quantitative single-cell gene expression profiling. Biol Reprod 75: 705-716.

YAMAGUCHI, S., KIMURA, H., TADA, M., NAKATSUJI, N. and TADA, T. (2005). Nanog expression in mouse germ cell development. Gene Expr Patterns 5: 639646.

YEOM, Y.I., FUHRMANN, G., OVITT, C.E., BREHM, A., OHBO, K., GROSS, M., HUBNER, K. and SCHOLER, H.R. (1996). Germline regulatory element of oct4 specific for the totipotent cycle of embryonal cells. Development 122: 881-894.

YING, Q.L., NICHOLS, J., CHAMBERS, I. and SMITH, A. (2003). Bmp induction of id proteins suppresses differentiation and sustains embryonic stem cell selfrenewal in collaboration with stat3. Cell 115: 281-292.

YING, Y., QI, X. and ZHAO, G.Q. (2001). Induction of primordial germ cells from murine epiblasts by synergistic action of bmp 4 and bmp8b signaling pathways. Proc Natl Acad Sci U S A 98: 7858-7862.
YING, Y. and ZHAO, G.Q. (2001). Cooperation of endoderm-derived bmp2 and extraembryonic ectoderm-derived bmp4 in primordial germ cell generation in the mouse. Dev Biol 232: 484-492.

YOUNGREN, K.K., COVENEY, D., PENG, X., BHATTACHARYA, C., SCHMIDT, L.S., NICKERSON, M.L., LAMB, B.T., DENG, J.M., BEHRINGER, R.R., CAPEL, B. et al. (2005). The ter mutation in the dead end gene causes germ cell loss and testicular germ cell tumours. Nature 435: 360-364.

YU, J., VODYANIK, M.A., SMUGA-OTTO, K., ANTOSIEWICZ-BOURGET, J., FRANE, J.L., TIAN, S., NIE, J., JONSDOTTIR, G.A., RUOTTI, V., STEWART, R. et al. (2007). Induced pluripotent stem cell lines derived from human somatic cells. Science 318: 1917-1920.

ZHAO, G.Q. and GARBERS, D.L. (2002). Male germ cell specification and differentiation. Dev Cell 2: 537-547.

\section{Further Related Reading, published previously in the Int. J. Dev. Biol.}

See our Special Issue Fertilization edited by Paul M. Wassarman and Victor D. Vacquier at:

http://www.ijdb.ehu.es/web/contents.php?vol=52\&issue=5-6

See our Special Issue Mammalian Reproduction and Development, edited by Brigid Hogan at:

http://www.ijdb.ehu.es/web/contents.php?vol=45\&issue=3

Interleukin-2 induces the proliferation of mouse primordial germ cells in vitro

Cristina Eguizabal, Maria D. Boyano, Alejandro Díez-Torre, Ricardo Andrade, Noelia Andollo, Massimo De Felici and Juan Aréchaga

Int. J. Dev. Biol. (2007) 51: 731-738

Primordial germ cell migration

Kathleen Molyneaux and Christopher Wylie

Int. J. Dev. Biol. (2004) 48: 537-543

Twenty years of research on primordial germ cells

M De Felici

Int. J. Dev. Biol. (2001) 45: 519-522

The allocation and differentiation of mouse primordial germ cells

T E Tsang, P L Khoo, R V Jamieson, S X Zhou, S L Ang, R Behringer and P P Tam

Int. J. Dev. Biol. (2001) 45: 549-555

Differentiation of mouse primordial germ cells into female or male germ cells

N Nakatsuji and S Chuma

Int. J. Dev. Biol. (2001) 45: 541-548

Germ cell biology - from generation to generation

P J Donovan, M P De Miguel, M P Hirano, M S Parsons and A J Lincoln

Int. J. Dev. Biol. (2001) 45: 523-531

Regulation of primordial germ cell development in the mouse

M De Felici

Int. J. Dev. Biol. (2000) 44: 575-580

Germ line development in fishes

A K Braat, J E Speksnijder and D Zivkovic

Int. J. Dev. Biol. (1999) 43: 745-760

Primordial germ cell development: is the urodele pattern closer to mammals than to anurans?

M Wakahara

Int. J. Dev. Biol. (1996) 40: 653-659

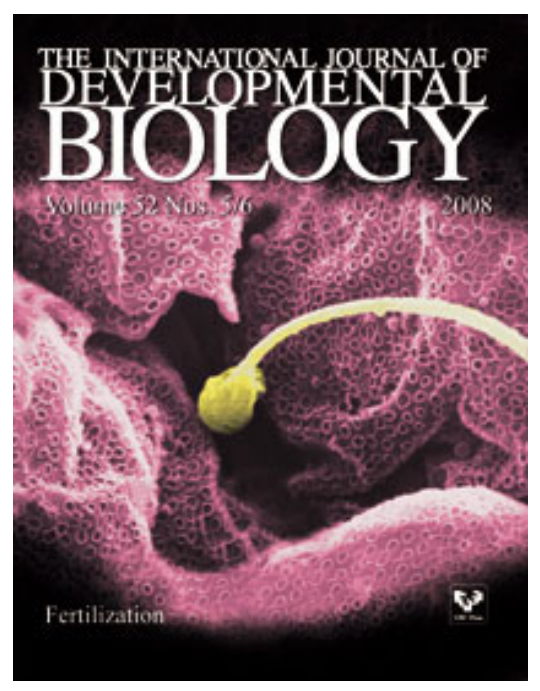

2006 ISI **Impact Factor $=3.577^{* *}$

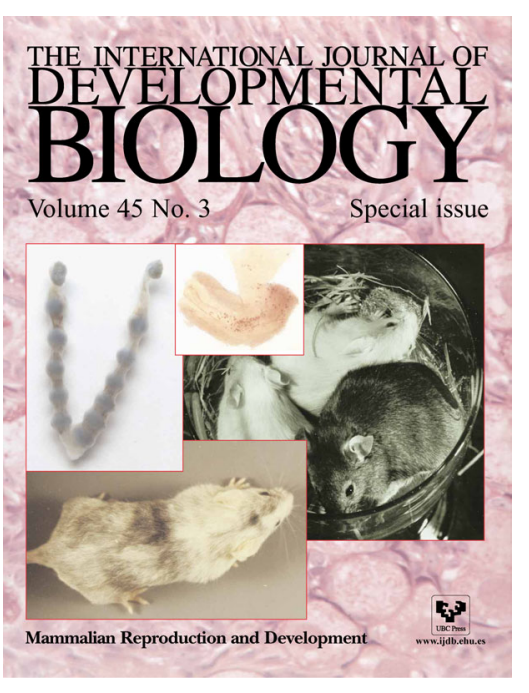

